\title{
EL JAGUAR TRANSFORMADO. UNA HIPÓTESIS POLIÉDRICA A PROPÓSITO DE LA DANZA EL CABALLITO BLANCO
}

\author{
JuAn Luis Ramírez TORRES \\ Universidad Autónoma del Estado de México
}

\begin{abstract}
Resumen: Desde las nociones de complejidad (Edgar Morin) y semiosfera (luri Lotman), y en el marco de la matriz cultural constituida por Mesoamérica, se analiza el sistema simbólico de la danza maya-chontal El Caballito Blanco, asociada sistémicamente al simbolismo del jaguar maya y mesoamericano. Para ello, se propone una estrategia metodológica consistente en la clasificación del conjunto simbólico - construido a lo largo de la historia por heterogéneos significantes y significados-, sustentada en la geometría del poliedro como una manera de pensar y ordenar analíticamente el continuum semiótico yokot'an, y sobre lo cual se propone una explicación respecto al proceso de transformaciones simbólicas ocurridas en el devenir cultural indígena desde el mítico felino hasta el ibérico equino, pero donde ambos quedan integrados en una misma estructura siempre de sentido Chontal-yokot'an, en lo particular y, de constantes mayas, en lo general.
\end{abstract}

Palabras clave: Jaguar, Caballito Blanco, chontal-yokot’an, complejidad, símbolo.

AвSTRACT: Starting from the notions of complexity (Edgar Morin) and semiosphere (luri Lotman) and in the framework of the cultural matrix constituted by Mesoamerica, we analyze the symbolic system of El Caballito Blanco (The Little White Horse), a Maya-Chontal dance, systematically associated to the symbolism of the Mayan and Mesoamerican jaguar. In order to do so, a methodological strategy is proposed; it consists in classifying the symbolic set constructed along history by heterogeneous signifiers and signifieds, supported on the geometry of the polyhedron as a way of thinking and analytically order the yokot'an semeiotic continuum and upon which we put forward an explanation for the process of symbolic transformations occurred in the indigenous cultural becoming, from the mythical feline to the Iberian equine, but where both are integrated in the same structure always with Chontal-yokot'an meaning, in particular, and with Mayan constants, in general.

KeY words: Jaguar, Little White Horse, Chontal-yokot'an, complexity, symbol.

RECEPCIÓN: $1^{\circ}$ de abril del 2011.

ACEPTACIÓN: 15 de agosto del 2011. 



\title{
EL JAGUAR TRANSFORMADO. UNA HIPÓTESIS POLIÉDRICA A PROPÓSITO DE LA DANZA EL CABALLITO BLANCO
}

\author{
JUAN LUIS RAmíreZ TORRES \\ Universidad Autónoma del Estado de México
}

\section{Introducción}

Lo humano es una sutileza caleidoscópica, una suerte de múltiples y complejas conjugaciones de formas tangibles e intangibles; esta composición es de tal arquitectura que rebasa la óptica binomial e implica, de menos, la perspectiva de una dimensión tripartita a la manera de un poliedro inconforme con la pura perspectiva unidireccional. No basta con marcar dos puntos y trazar una línea; lo humano puede ser recto, pero suele existir también la hechura con volumen e, incluso, en planos reflejos a la manera de dos espejos que se proyectan mutuamente en un infinito que, por momentos, confundirá al observador al no saber dónde empieza lo uno y dónde lo otro, dónde es él, y dónde ese alter desdoblado de su yo: "Así es que el mundo está en el interior de nuestro espíritu, el cual está en el interior del mundo. En ese proceso, sujeto y objeto son constitutivos uno del otro" (Morin, 2005a: 69).

La obra humana, la cultura, humaniza a la materia viva, biología del hombre, masa dialéctica integral de la condición humana, para la cual "no hallamos en su interior ninguna muralla china que separe su parte humana de su parte natural. Es evidente que cada hombre es una totalidad bio-psico-sociológica" (Morin, 2005b: 21). Esta totalidad nos ubica en un marco que reconoce su complejidad definitoria de sí misma, por lo que la presente reflexión "aspira al pensamiento multidimensional... [que] implica el reconocimiento de un principio de incompletud y de incertidumbre" (Morin, 2005a: 23). Consecuentemente, dejaremos que la incompletud y la incertidumbre sean la balsa sobre la que naveguemos en la presente propuesta; para ello partamos de algunos cabos - los de una ciencia todavía fragmentada—, a saber, el símbolo — como unidad básica de análisis—, la complejidad, y la noción de semiosfera; todo ello enmarcado en el gran escenario cultural de Mesoamérica. Esto se encarna - en tanto que experiencia colectiva de vida - en la danza maya-chontal de El Caballito Blanco, celebrada en las festividades de san Antonio de Padua, en la comunidad Buenavista Primera Sección, el 13 de junio, y en las honras a san Francisco de Asís, el 4 de octubre, en Tamulté de las Sabanas, ambos del municipio Centro, en el estado de Tabasco, México, y en la que se observa el complejo juego de espejos significativos derivado del 
continuum semiótico en las transformaciones simbólicas al interior de la semiosfera yokot'an. ${ }^{1}$

\section{Las formas en el tiempo: un caballito de conquista}

Acaso un primer garabato ecuestre quedó bosquejado hacia 1518 cuando arribaron fuerzas españolas encabezadas por el capitán de nombre Juan de Grijalva a la desembocadura de un río que, posteriormente y hasta nuestros días, es identificado con el apellido de este mismo personaje. Un año más tarde, Hernán Cortés cruza por el mismo lugar para avanzar tierra adentro, encontrando la resistencia de los nativos que serían finalmente derrotados en lo militar; en esos combates "Es de suponer que los caballos, tan desconocidos por los indios como las ballestas que escupían fuego, tuvieron en ellos efectos desalentadores" (Martínez Assad, 1996: 26-27). Por su localización geográfica es posible deducir que los pueblos que resistieron la invasión ibérica fueron precisamente los chontales, en su lengua materna yokot'an, quienes se incorporarían así al proceso colonial y a las posteriores etapas históricas de la nación mexicana, ya como parte del estado de Tabasco y de municipios y comunidades actualmente identificadas.

A este hecho histórico se atribuye la danza actual de El Caballito Blanco (figuras 1 y 2), ya que en ella se representa aquel enfrentamiento donde habría resultado vencido el guerrero nativo. Al respecto, el etnólogo Miguel Ángel Rubio indica:

Al asumirse como indígenas, los chontales de Tamulté se ven a sí mismos —a través del personaje de la máscara- como uno de los tantos pueblos vencidos. La trilogía máscara-indígena-derrotado es un estigma que prevalece en su conciencia cotidiana y en los mitos que narran la antigua derrota militar. Más aún, sus propios relatos mítico-históricos recuerdan permanentemente la sustitución del ancestral culto a una de sus deidades más importantes, Kantepec, por el que rinden a quien, desde hace cinco siglos, ha pregonado el cristianismo en suelo americano.

En contraste, la figura del caballito, asociada con el español, es estimada como una entidad casi reverencial, animada y vital. El trato de privilegio que se le concede cada año en la fiesta, "alimentándolo" con pastura, maíz y agua, da una idea de la importancia que se le asigna, no sólo al animal en sí, sino a lo que éste representa para los indígenas: caballito-español-victoria. Los símbolos que exhibe no dejan lugar a dudas: en el pecho lleva el emblema de la cruz, y sobre su lomo, al jinete con la espada ensangrentada, que remite a la herida del adversario (Rubio, 1996a: 247).

Entre la explicación académica —inserta en la lógica racional—y la perspectiva indígena se halla el libro bilinguie Palabra y pensamiento Yokot'an, escrito en co-autoría por Rodolfo Uribe Iniesta, sociólogo, y Bartola May May, estudiosa de la cultura chontal a la vez que originaria de una de sus comunidades; ellos apuntan respecto a la invasión española lo siguiente:

\footnotetext{
${ }^{1}$ Autodenominación del Pueblo Maya-Chontal de Tabasco, en su lengua materna.
} 


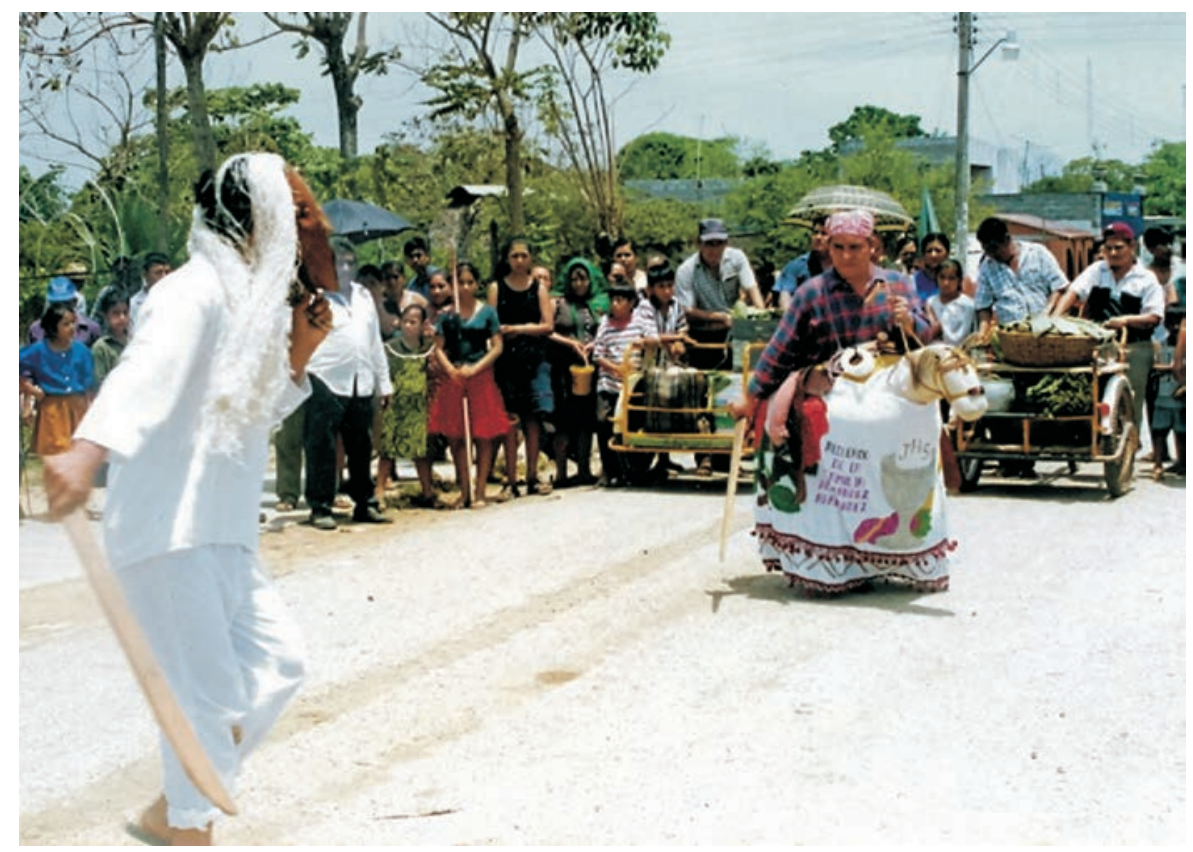

Figura 1. Máscara Roja y Caballito Blanco de Buenavista Primera Sección. Foto de Juan Luis Ramírez Torres

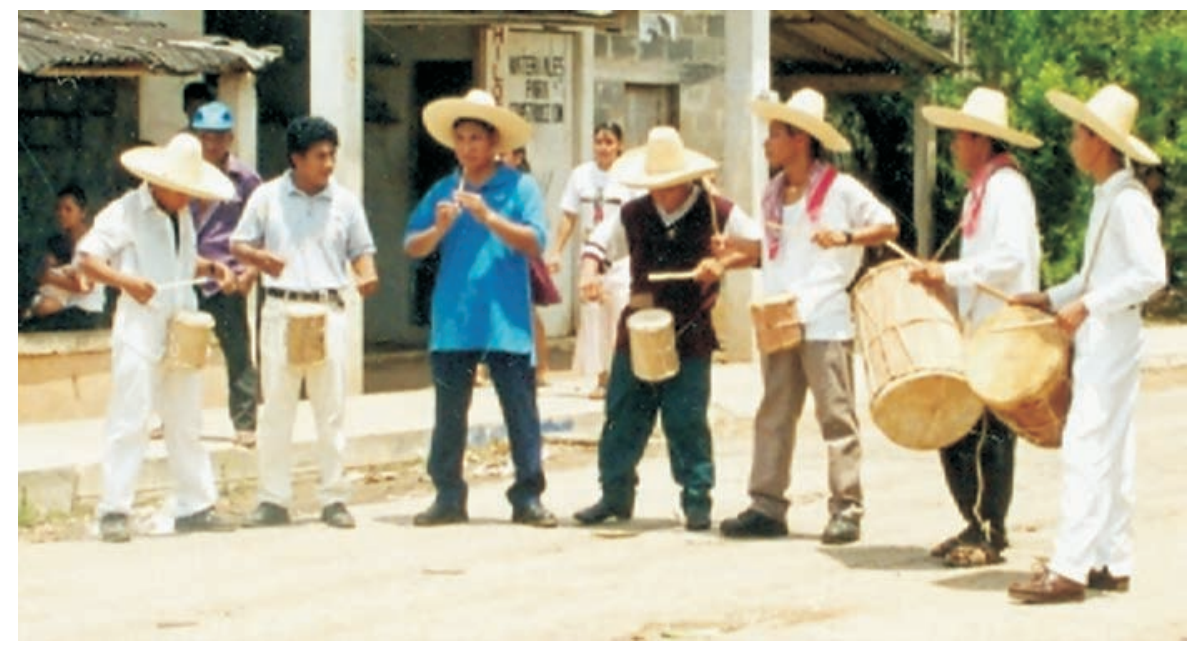

Figura 2. Tamborileros de Buenavista Primera Sección. Foto de Juan Luis Ramírez Torres 
El 25 de marzo de 1519, con grandes trabajos, atacando por la retaguardia, Cortés venció en batalla a los señores de Potonchán-Tabasco en Centla; se llamó dueño de este territorio, hiriendo con tres cuchilladas la ceiba de la plaza [...].

Como Garrido, los españoles destruyeron los altares y los ídolos y no aceptaron la religión yokot'an. Jonuta resistió, matando al catecismo cristiano. El rey lo sancionó desapareciendo el pueblo. En 1575, el obispo Landa torturó y mató a muchos sacerdotes, curanderos, hierbateros y recomendadores indígenas. En 1631, se prohibió, en Tamulté de las Sabanas, la danza del tigre, por entregar ofrendas a Kantepec. Se les prohibió porque sacrificaban gallinas y se simulaba el sacrificio de un individuo que era entregado a los tigres. Los caciques entregaban los ídolos y acusaban a los curanderos para ganar el favor de los españoles. Tardó mucho la religión yokot'an en resurgir con nuevas prácticas cristianas... (Uribe Iniesta y May May, 2000: 35-36 y 45-46).

Por su parte, al interior de la comunidad chontal, específicamente en el poblado de Buenavista Primera Sección, existe un relato escrito en español, de este proceso que ilustra, prácticamente a la manera de una radiografía, el tránsito de un pasaje histórico a un relato mítico; dada su relevancia se expone a continuación el documento referido en su totalidad: ${ }^{2}$

Aproximadamente en el año de 1500, en la vieja estancia, actualmente villa tamulté de las sabanas y sus comunidades vecinas en esta provincia de tabasco, se bailaba la danza del tigre; donde se disfrazaban de dicho animal y danzando hacen toda clase de actos; los tigres simulan pelear con un indio que se vestía de guerrero, al que amarran y simulan sacrificar en una cueva que le llaman "la cueva del K'ANTEPEC" don de [donde] en lugar del indio sacrificaban gallinas como ofrenda a su dios, recordando las viejas costumbres de sus antepasados; durante todo este acto tocaban música autóctona, gritaban y bebían fermentos que los dejaban en estado lastimosos hasta caer rendidos.

Paso varios años, cuando el 12 de marzo de 1519, Hernán Cortes toma por conquista el territorio tabasqueño, esto dio lugar, que el 13 de marzo se lleve a cabo la batalla de Centla (cerca del lugar donde se establecían estos indígenas de la vieja estancia), donde aparecieron hombres montados a caballos armados de lanzas y dando batalla entre los indígenas, estos se atemorizaron, porque pensaron que eran dioses.

Con la conquista de este territorio llega a establecerse también la iglesia católica, estando todavía en su auge la santa inquisición, en 1631, los indígenas todavía bailaban la danza del tigre, pero al dominar más la santa inquisición en el aspecto religioso, prohibido este tipo de danza, porque los actos realizados en ella, estaban en contra de la religión de aquellos tiempos, pero los indígenas no respetaron esas leyes, por lo que comenzaron a practicarlo a escondidas en casa de los mayordomos o principales de las comunidades, teniendo un cambio en sus ritos, porque en esta aparecía un hombre danzando con una máscara puesta y no era acompañado por los hombres disfrazados de tigres, cambiándole también el nombre de la danza: "EL K'OYA" que significa Enfermedad Maligna representado en dos formas,

\footnotetext{
${ }^{2}$ Se respetan redacción, ortografía y énfasis originales.
} 
hombre bueno y malo. Hoy en día se bailan en la comunidad de la zona indígena de la Sabana, en el maromo de las fiestas patronales.

Más tarde sucedió que, recordando la conquista de 1519 y recordando la batalla, los indígenas hicieron un caballito blanco, porque pensaban que en ese entonces de la batalla, que los hombres montados a caballos eran mitad hombre y mitad animal y de esta manera completaron su danza imitando tal y como había sucedido en la batalla de Centla, así nace la danza del caballito blanco o danza de conquista.

La danza de conquista lo hacen a través de las mímicas expresando el deseo de pelear; el Español raya y baila su caballo amenazando al mismo tiempo con la espada; el CHONTAL ó el K'OYA se inca para afilar su machete y amenaza con atacar, los pasos de ambos son diferentes; el Español sostiene todo el tiempo un paso de galope simple de planta y algunas veces lo puntea, sobre todo cuando a atacar. El CHONTAL, ejecuta un de paso cambio parecido al primer paso del zapateado, sólo que aquí, en vez de ser figurado lo ejecuta en forma simple.

Ambos usan un balseado [valseado] para desplazarse entre el juego de expresión corporal y la mímica; por ejemplo, cuando el español golpea al chontal en la cara, este retrocede haciendo expresiones de dolor con la cabeza y brazos, toca toda la máscara y se ve la mano como si esta estuviera ensangrentada.

Al final cae el K'OYA después de haber sido empujado por el caballo durante un buen trayecto para ser atropellado al final, allí el chontal clava su machete en el flanco del caballo y al mismo tiempo el español pone la punta de la espada en el pecho del K'OYA.

(INVESTIGACIÓN HECHA POR LOS NATURALES [sic] DE BUENAVISTA, TAMULTE DE LAS SABANAS, CENTRO, TABASCO) (Anónimo, s/f)

Presumiblemente, la primera fuente escrita de estas versiones fue el testimonio dejado por fray Sebastián Villela en 1631 y que Carlos Navarrete dio a conocer en la década de los setenta. Ese documento se transcribe a continuación.

En el pueblo de Tamulté desta provincia de Tabasco, en los siete días del mes de junio de mil y seiscientos y treinta y uno, yo el Religioso encargado del culto en este pueblo, notifiqué a los naturales y a dos autoridades del pueblo de Sabana que también corre a mi cargo y cuidado, la disposición recibida... [párrafo tachado e ilegible]... [el] cual dijo: que estando presto a acatar y cumplir los mandatos de la Santa Inquisición; que en estos se prohíbe todo baile que tenga y encumbra idolatrías y toda clase de ofensas contra nuestra Religión y se haga vigilancia dellos; en vista de los informes que le han llegado sobre la forma en que se lleva el baile que llaman del tigre, donde se disfrasan de dicho animal y danzando hacen toda clase de actos contra nuestra Fe; que tuvo informes de que en dicha representación los tigres simulan pelear contra un indio que viste de guerrero, al que amarran y simulan sacrificar en una cueva que llaman Cantepec, donde hacen música y gritan y beben fermentos que los dejan en estados lastimoso hasta caer rendidos; y como sabe de buenos informes que en lugar del indio sacrifican gallinas, que es lo mismo, pues es mal arraigado en la viejas costumbres gentiles de sus antepasados, sin importar que niños inocentes y mujeres tengan a la vista tan cruel rito, y que como a pesar de los continuos sermones y consejos que reciben de sus ministros en la Fe de Cristo persisten en sus idolatrías y sacrificios, ha tenido a justicia disponer 
se comunique a todos los pueblos de la Provincia, del cual uno de este susodicho de Tamulte, que no se baile ni se consienta en bailar por pernisioso, so pena de cien azotes y destierro de sus pueblos y excomunión. Mandato que... [tachado e ilegible]... [no]tificar a los naturales principales, que se disculparon y rogaron se les siga permitiendo dicho baile sin borrachera y sacrificios, a lo que yo respondí con energía para estorbar su pretensión de continuar tan sacrílega costumbre. Y así notifiqué y lo firmo. (f) Fray Sebastián Villela. (Navarrete, 1971: 374-376).

Lo anterior evidencia la mención constante a Cantepec ${ }^{3}$ y al Tigre, ambos asociados con los relatos que hablan de los antecedentes de la actual danza de $E l$ Caballito. De esta suerte es que partimos del encadenamiento compuesto por Caballito Blanco/Máscara Roja/Cantepec/Tigre, y sobre el cual descansamos la presunción hipotética de una conexión ritual consistente en la transferencia simbólica desde el Jaguar-Tigre hasta el Caballito Blanco, constituyéndose así un continuum de significación entre el felino mesoamericano y el equino europeo. En consecuencia, reconocemos la presencia de los personajes Máscara y Caballito como un primer par de opuestos que se confrontan al luchar con sus armas, pero a lo cual se suma aquí, desde ese primer esquema dual de enfrentamiento, el desdoblamiento — a la manera de las imágenes reflejadas en espejos encontrados- del personaje indígena aparentemente derrotado, que transita al indio guerrero sacrificado en la Danza del Tigre, por lo que estaríamos ante el caso de un rito cuya composición ha atravesado por un proceso de transformación simbólica.

\section{Las formas en el espacio: un danzar geométrico}

Edmund Leach considera que “...un signum es un símbolo cuando A representa a B y no hay relación intrínseca previa entre A y B, es decir, A y B pertenecen a contextos culturales diferentes" (Leach, 1981: 20). Principio definitorio que se considera aquí concordante con las ideas de Mircea Eliade al respecto, particularmente en lo tocante a lo sagrado, momento en que reconoce que la función del símbolo es "...transformar un objeto o un acto en algo diferente, de lo que ese objeto o ese acto muestra ser en la perspectiva de la experiencia profana” (Eliade, 1986: 398). En tanto que el símbolo forma parte de un sistema estructurado, resulta que una cualidad de éste y aquél es el de la transformación, Jean Piaget señala al respecto que la estructura "es un sistema de transformaciones", caracterizado además por la totalidad y la autorregulación (Piaget, 1980: 9). Es así que “... cuando intentamos interpretar celebraciones rituales tendemos a olvidar que acontecimientos que están separados por un intervalo considerable de tiempo pueden formar parte del mismo mensaje" (Leach, 1981: 35-36); por lo que, y en palabras de Eliade, “...la transmisión de los símbolos de un dios a otro es un fenómeno corriente en la historia de las religiones” (Eliade, 1986: 399), dado el

\footnotetext{
${ }^{3}$ Nombre de la divinidad chontal escrita aquí conforme la ortografía del español.
} 
rasgo característico del símbolo que es "la simultaneidad de los sentidos que revela" (Eliade, 1986: 402).

En consecuencia, el vínculo estructural entre el Jaguar/Tigre y el Caballito Blanco es un proceso de transformación simbólica, donde los significantes diversos Jaguar-Tigre-Caballito, equivalen a un continum semiótico - es decir, a una semiosfera $-{ }^{4}$ a lo largo de ese otro continuum constituido por las formas religiosas mesoamericanas precolombinas y el catolicismo practicado y concebido en el contexto maya-chontal, que al combinarse en sus distintas influencias ocurridas históricamente (de guerrero sacrificado por el jaguar, al indígena vencido por el invasor ibérico) da una mixtura polisémica, fincada en símbolos que, transformándose, dan cuenta de un mensaje simultáneamente constante a la vez que renovado contextualmente a lo largo del devenir histórico maya-chontal.

La lógica simbólica posee una característica dialéctica que, en las consideraciones de Eliade, integra zonas y sectores de la experiencia antropocósmica, identificando en torno suyo objetos, situaciones y modalidades que permiten así la circulación e incorporación de esferas diversas en un todo; es decir, en un sistema sintetizando la multiplicidad en una situación única, a tal grado que el hombre mismo se transforma en símbolo (Eliade, 1986: 404-407). Consiguientemente, Jaguar, Tigre, Caballo, Guerrero, Máscara Roja, Indígena Chontal son partes de ese todo que se permiten deambular a lo largo de la historia nativa, pero no en una geometría lineal, ni tampoco circular, sino de un tipo poliédrico, con múltiples vértices que en sus interconexiones forman un cuerpo geométrico semiótico, volumen que para nuestro caso equivale propiamente a un sistema: "asociación combinatoria de elementos diferentes" (Morin, 2005a: 41); y que sustento en los referentes de una etnología que ha reconocido que la sociedad comprende un conjunto de estructuras que corresponden a diversos tipos de órdenes factibles de ser tejidos entre sí (Lévi-Strauss, 1977: 285), perspectiva compatible con la de otros campos desde donde se entiende a la estructura como sistema de transformaciones en tanto totalidad que se autorregula (Piaget, 1980: 9-10), y que en el vínculo orden/desorden sucede la vida como sistema de reorganización permanente fundado en una lógica de la complejidad (Morin, 2005b: 26). Por ello, los vértices sistémicos de un poliedro lo mismo conectan dos o tres parcelas, como en las adherencias estructurales que se ordenan binariamente en parejas, pero que cuando uno de sus dos puntos se conecta con un tercer binomio constituye una triada, es decir un sistema binario-triádico (Ramírez Torres, 2000). Este tipo de estructura sirve aquí como un modo de ver y pensar en poliédrico —-de pensar de manera compleja—; esto es, en interconexiones binarias y triádicas

\footnotetext{
4 "Tomado por separado, ninguno de ellos tiene, en realidad, capacidad de trabajar. Sólo funcionan estando sumergidos en un continuum semiótico, completamente ocupado por formaciones semióticas de diversos tipos y que se hallan en diversos niveles de organización. A ese continuum, por analogía con el concepto de biosfera introducido por V. I. Vernadski, lo llamamos semiosfera" (Lotman, 1996: 22).
} 
que transitan en forma múltiple, y no lineal ni circular, en el devenir histórico y concretado, para este caso, en el sistema ritual y dancístico chontal.

\section{La danza dentro del poliedro}

Nuestra perspectiva conduce a una primera mirada obligadamente parcial respecto a los conceptos del mundo sagrado maya, ya que en el viaje por el poliedro ha de iniciarse el recorrido andando por una primera línea recta para, posteriormente, entroncar con otras y después continuar los pasos por otras interconexiones. De aquí que partamos desde un primer punto de referencia. Sylvanus G. Morley indica que el maíz divinizado fue representado en la condición de un hombre joven, ocasionalmente ornamentado por una mazorca sobre su cabeza, se ignora el nombre asignado en aquel entonces, y pudo confundirse con una deidad agrícola más generalmente conocida como Yum Kax, Señor de los Bosques (Morley, 1994: 213). Fue representado gráficamente de manera cruciforme (Ruz Lhuillier, 1995 : 47), ejemplo de ello son la cruz y el árbol de la vida, ambos esculpidos en los bajorrelieves de Palenque (Soustelle, 1988: 175); el mismo Morley señala que algunas de sus funciones fueron asumidas por el dios Chaac (Morley, 1994: 213).

Junto a la divinidad pluvial, participan de su simbolismo cuatripartita el rojo relativo al este, el blanco al norte, el negro al oeste y el amarillo al sur, puntos cardinales donde se localizan otros tantos Chaaques con los mismos colores de los Pauahtunes, quienes envían el viento asociado al rayo y el trueno, éstos simbolizados por el hacha y el tambor en los códices. Cabe agregar en este complejo en torno de la lluvia a Chicchan, de quien Ruz Lhuillier apunta su posible vinculación a Chaac, la cual es una serpiente aún adorada como proveedora de lluvia entre algunos pueblos mayas (Ruz Lhuillier, 1995: 47-49). Es pertinente subrayar que Chaac, en su representación en los códices, aparece sosteniendo en la mano un hacha, ya referida, de pedernal, respecto a lo cual Soustelle reitera que es símbolo del rayo y el trueno (Soustelle, 1988: 179).

El carácter dual del simbolismo en torno de Chaac es observado por Morley en los códices; en ellos cuida un árbol joven, seguido de Ah Puch, dios de la muerte, quien rompe el mismo árbol en dos. Para revertir estos peligros, es menester ofrendar al dios objetos o personas en sacrificio, tal es el caso para propiciar las lluvias; también se utiliza la sangre humana o de algún animal, para rociar con ella los ídolos y embadurnarles el rostro (Morley, 1994: 206-207). El sistema ritual a él dedicado se caracteriza por ayunos, abstinencia, ofrendas de flores, frutos, alimentos, animales, autosacrificios y sacrificios humanos. A ello se sumaba la música y la danza; de la primera se refiere la existencia de instrumentos musicales, no forzosamente relacionadas con el rito, como los de percusión: tunkul y pax, timbales de barro, sonajas, cascabeles de metal, carapachos de tortuga tañidos con asta de venado, raspadores estriados de hueso, trompetas de madera, caracoles marinos, flautas de barro, carrizo y hueso, silbatos y ocarinas de barro (Ruz Lhuillier, 1995: 52 y 67). Por su parte, Eric Sidney Thompson 
menciona que "los danzantes se ponían máscaras especiales para representar a los dioses [y] se ejecutaban danzas para influir favorablemente en los resultados de la caza y para obtener buenas cosechas" (Thompson, 1992: 348). Morley, por su parte, narra la ceremonia del mes pax, dedicada al dios Cit Chac Coh, "Padre Puma Colorado”, patrono de los combatientes; para esa ocasión se bailaba el holcánokot, danza de los guerreros, como parte del rito encaminado a lograr la victoria en las acciones bélicas (Morley, 1994: 237).

Transitando a otro punto referencial, fray Diego de Landa dejó testimonio de la puntualidad de la danza en la simbólica ritual maya. Comencemos con la hecha sobre el par constituido por juego de cañas, colomché, y otro donde convergían alrededor de ochocientos participantes con banderas pequeñas, en son y paso largo de guerra. Había otro ejecutado por mujeres y hombres, llamado Anual no muy honesto en palabras del fraile franciscano. En las fiestas de los días aciagos, entre sacrificios de aves, perros e incluso humanos, se cumplía el protagonizado por las viejas del pueblo ataviadas de ropas especiales. En el año Muluc, se ejecutaban los de guerra nombrados holcanokot betelokot. Para el culto a Yaxcocahmut se realizaba la ceremonia caracterizada por llevar zancos muy altos, mientras que mujeres ancianas lo hacían portando figuras de perros elaboradas con barro. En el año $I x$, con aguiero Zaczini, la danza para esa ocasión se denominaba alcabtan Kamahau. Para el año Cauac y aguiero Hozanek, actuaban uno como cazcarientas, por ello llamado Xibalbaokot; junto al anterior un personaje cantaba y tañía un tambor a la vez que bailaban todos los de abajo con mucho concierto y devoción. Como ya se dijo, en la veintena de Pax llevaban a cabo uno donde lo hacían con paso largo de guerra, llamado Holkanakot: baile de guerreros; en las fiestas Zabacilthan también hacían bailes; en torno del año nuevo, en el espacio sagrado se juntaban únicamente varones a excepción de las mujeres mayores quienes hacían sus bailes. Durante el mes Uo terminaba la celebración con el baile Okotuil; al día siguiente, los médicos, en la fiesta Ihcillxchel, y portando a cuestas sus envoltorios de medicinas, danzaban el llamado Chan-tun-yab; al tercer día, eran los cazadores quienes, llevando flecha y calavera de venado pintadas de azul, bailaban con ellas en las manos, para después seguir haciéndolo entre bebidas y embriaguez; les seguían los pescadores, los cuales, con los aparejos propios de su oficio, bailaban el Chohom. En la fecha Xul pasaban cinco días con sus noches entre oraciones y bailes devotos (Landa; 1982: 38ss.). Todo esto sustenta lo afirmado por Alberto Ruz: "Por lo general todas estas fiestas incluían danzas..." (Ruz Lhuillier, 1992: 203).

Así es que respecto a la danza en el año que recibía la carga del día muluc -en la cual, como ya se ha referido, las mujeres ancianas bailaban con perros de barro-, Martha Ilia Nájera señala su coincidente mención en el Códice Madrid (páginas 34 a 37), donde se miran escenas como danza en zancos, de mujeres ancianas, y aquellas con pequeños perros y en sacrificio (Nájera, 2002: 120-121, 123, 124). Esta misma autora, citando pasajes del Libro de los Cantares de Dzitbalché, señala que en la ritualidad de connotación femenina y fertilidad, mujeres 
jóvenes vírgenes, dirigidas por una anciana, danzaban desnudas con la luz lunar y junto a una poza de agua (Nájera, 2002: 126-127).

Más allá de las fuentes escritas en los caracteres occidentales, la iconografía, y en general la plástica maya, ofrece datos de la relevancia dancística. Desde tal perspectiva, por ejemplo, Beatriz de la Fuente cita los casos del Mural de las Cinco Eras en donde se aprecia a un danzante que carga una cabeza humana con su mano; otra escena se halla en los vasos del Altar de los Sacrificios, en la que los personajes (GI y GIII) toman una "postura ritual considerada de baile, a la que se llama Danza de Xibalbá” (De la Fuente, 2002: 148 y 151).

En suma, la danza es un actor constante en la ritualidad maya precolombina; este protagonismo evidencia su permanencia hasta el presente, incluso, no sólo como baile, sino en todo su complejo coreográfico-musical en los tiempos y espacios sagrados. Ocurre así una geometría donde rito y música conforman un vértice que inmediatamente se triangula con la danza (figura 3), dejando extremos de sus líneas para hacer otras variadas conexiones que su dinámica sociohistórica demande al interior del poliedro social maya.

\section{Los dioses en el poliedro}

Por la danza, los hombres se transformaban en los personajes representados en un "realismo dramático mediante las máscaras y los trajes" utilizados (Freidel,

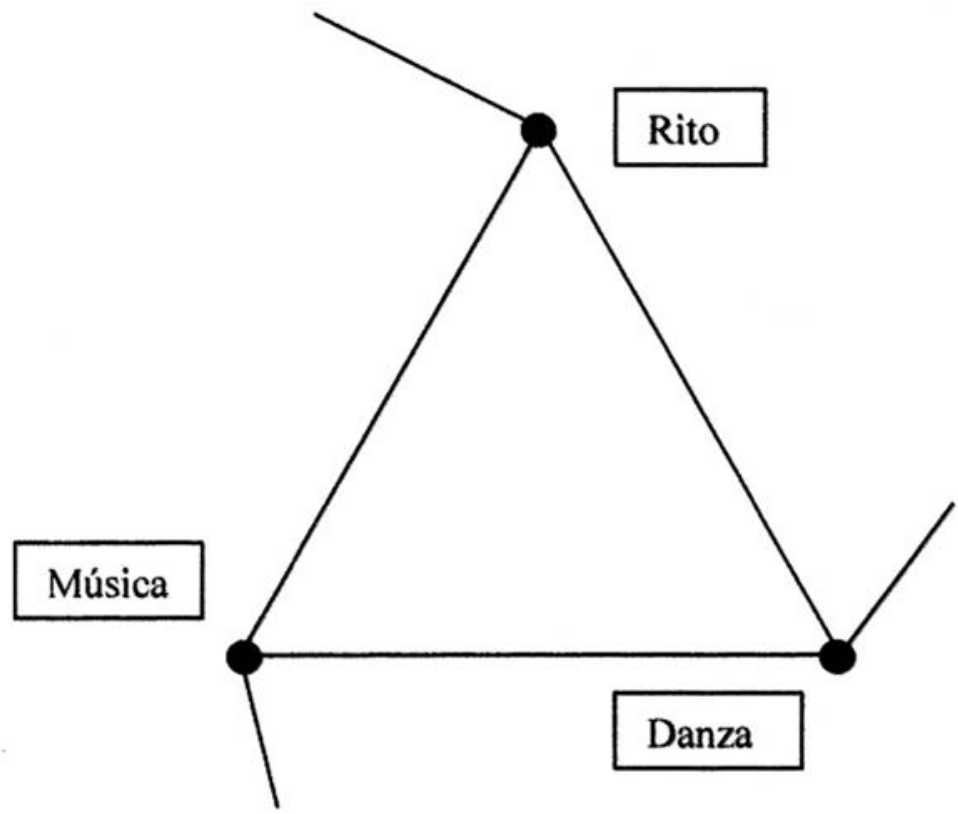

Figura 3. Primera triangulación.

Dibujo de Juan Luis Ramírez Torres 
Schele y Parker, 1999: 257); de donde el baile sagrado deriva en canal de transformación; es decir, de trascender una forma primera, para adquirir una nueva hechura y con ello otras cualidades, por lo que es a través de la danza que los seres humanos se transforman en dioses y los dioses en seres humanos. Y es entre los teatros simbólico-rituales que los vértices del poliedro se hacen particularmente polisémicos y complejos.

Resultan así figuras como las mencionadas por De la Fuente para la pareja Sol-Venus que no se modifica sustancialmente al conservar los signos k'in y yax, pero, de otra parte, se multiplica en dioses alternos, como el Sol diferenciándose diurno o nocturno, o Venus dividiéndose en dioses emparentados (De la Fuente, 2002: 162-163). De tal versatilidad participan también los hombres terrenales, quienes "al disfrazarse y usar máscaras se vuelven receptáculo y recurso de acción de los dioses. No es gratuito entonces que el señor Uaxaklahun Ubah K'awil se disfrace como G I, G III, G II, el Monstruo Cósmico, el dios del Maíz o baile la 'Danza de Xibalbá'...” (De la Fuente, 2002: 164).

La ambivalencia entre divinidades y el vínculo hombre-dioses no es privativo de una época, sino un continuum histórico que ha transitado por los diversos periodos desde el Preclásico, pasando por la Colonia y continuando hasta nuestros días. En este sentido, el actual calendario de fiestas religiosas en la región que nos ocupa permite acercarnos al escenario ritual chontal contemporáneo que, por lo que se puede observar, sigue en la misma multiplicidad que en el pasado; muestra de ello son las distintas imágenes de culto católico ${ }^{5}$ este sistema, fundamentalmente icónico, ${ }^{6}$ evidencia una estructura factible de dividirse en, al menos, tres apartados: 1) imágenes correspondientes a Jesucristo; 2) las pertenecientes a las advocaciones marianas; y 3) las que reúnen a santos, de donde resultan las siguientes seriaciones.

JesuCRIsto: Señor de Esquipulas, Señor de Tabasco, Señor Samaritano, Santa Cruz, Corpus Christi.

advocaCiones Virgen de la Asunción, Virgen de la Candelaria, Virgen del Carmen,

MARIANAS: Virgen de la Concepción, Virgen de Guadalupe.

SAntos: san Antonio de Padua, san Carlos, san Francisco de Asís, san Isidro Labrador, san José, san Juan Bautista, san Lorenzo, san Marcos, san Martín, san Mateo, san Miguel Arcángel, san Pablo, san Pedro, san Román, Santiago apóstol, santo Domingo.

SANTAS: santa Ana, santa Lucía.

Con base en lo anterior, se considera que, en el catolicismo popular, al menos en el correspondiente a Mesoamérica, el ámbito de sus divinidades queda articu-

\footnotetext{
${ }^{5}$ Este listado se fundamenta en los registros de Incháustegui (1985), Mora y González (1981), y Rubio (1995).

${ }^{6}$ En la medida en que sus representaciones quedan plasmadas en la numerosas imágenes que reciben culto en altares familiares y templos.
} 
lado por una pareja no exactamente "primigenia", pero sí fundacional, constituida por la Virgen María (en cualquiera de sus advocaciones) y Jesucristo (Ramírez Torres, 2003). En ella el esperado papel de "modelo" mítico como paradigma para el orden social resulta complejamente trastocado, ya que en este binomio Ella es la Madre, y Él, el Hijo; esto al mismo tiempo que el habla popular reconoce en aquella a su Madrecita, mientras que en éste mira a Papá Diosito. Tal adjetivación confronta el modelo católico reconocido en la Sagrada Familia, conformado por San José, el padre; la Virgen María, la madre; y Jesús, el hijo; sobra mencionar que el carácter paterno de san José posee un bajo perfil en el santoral católico y que el estatus de Padre no queda a discusión para Dios Padre, o Jesús-Papá Diosito, pero no asumido por el creyente común en la imagen del santo carpintero. ${ }^{7}$ En consecuencia, el símbolo de Jesús reúne en su persona la representación del Hijo, sacrificado, a la vez que la del Padre Nuestro ${ }^{8}$ un Padre que no es solo de su mismo Hijo Jesús, sino un padre que lo es de los hombres en la Tierra; junto a ello este mismo Padre no hace pareja gestante con la Madre, la Virgen María —una afirmación así resulta aberrante a los oídos del creyente católico-, por el contrario, Jesús mantiene esa descendencia de la Madre Virgen (figura 4).

Toda esta complejidad nos acerca a esa otra, la precolombina, y respecto a las que hemos afirmado media entre ambas un continuum estructural para con su sistema simbólico; en otras palabras, el poliedro del catolicismo popular contemporáneo es resultado de otros poliedros antecedentes, ubicados éstos en el

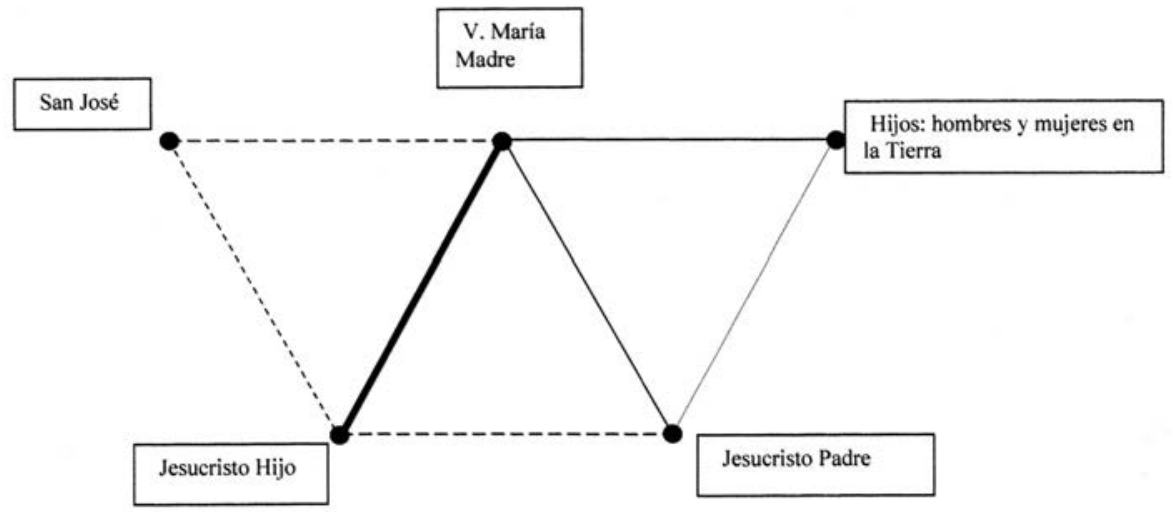

Figura 4. Desdoblamiento de triangulaciones. Dibujo: Juan Luis Ramírez Torres

\footnotetext{
${ }^{7}$ Este hecho, considero, obedece a la estructura de la familia en Mesoamérica, vertebrada por la madre (la madre biológica, o simbolizada por la abuela, la tía o la hija mayor), en lo que Oscar Lewis denominó Matrifocalidad (Lewis, 1986). De aquí la relevancia de la Virgen de Guadalupe en la cultura, identidad e historia nacional mexicana: madre de los mexicanos. Con un hijo, Jesús, que es al mismo tiempo el Padre divino, pero sin ser la pareja de María.

${ }^{8}$ ¿A quién rezan los creyentes la oración del Padre nuestro?, ¿a la Primera Persona, Dios Padre, o a la Segunda, Jesucristo?
} 
universo mesoamericano precolombino. Félix Báez-Jorge señala que "las expresiones cúlticas resultantes del proceso de evangelización...pueden caracterizarse en términos de desplazamiento..., sincretismo y simultaneidad" (Báez-Jorge, 2000: 186); es decir, no ocurre un proceso unilineal ni simplistamente sustitutivo. El desarrollo histórico de las religiones entre las etapas precolombinas, pasando por la Colonia y hasta el presente obedecen a mecanismos mucho más complejos que evidencian esas mentalidades igualmente complejas que les han dado origen. Por ello, Mario Humberto Ruz habla de tales procedimientos como un "amarrar junto ese verdadero caleidoscopio de luces y sombras" religioso cuyos integrantes divinos son personajes por derecho propio (Ruz, 2002: 248 y 267). Por tanto, cada forma caleidoscópica del sistema sagrado maya, a lo largo de su historia, es un aquí y un ahora en sí mismo, inserto en derivaciones y transformaciones - cuales cuentas de vidrio girando y girando entre tres espejos dentro de un cilindro-, pero donde a cada paso ha de asumirse, igual que en el caleidoscopio, la presencia de una figura singular, de existencia propia, y, por ende, de legitimidad, funcionalidad, y estructuración específicas. ${ }^{9}$

Dado lo anterior, es menester dejar abierta la tarea de una conectividad más compleja donde el maíz divinizado representa un hombre joven, ornamentado con una mazorca sobre su cabeza, y que hace intersección con la deidad agrícola conocida como Yum Kax, Señor de los Bosques (Morley, 1994: 213), y con su representación cruciforme (Ruz Lhuillier, 1995: 47) en los ejemplos de la cruz y el árbol de la vida esculpidos en Palenque (Soustelle, 1988: 175), amén de las asociaciones con el dios Chaac, los Chaaques, el viento, el rayo y el trueno, simbolizados a su vez por el hacha y tambor en los códices (Ruz Lhuillier, 1995: 47 y 49); por lo que, antes que evidencias de un proceso evolutivo ${ }^{10}$ unilineal, las percibimos como dispositivos de un gran poliedro que se construye históricamente en el seno de una estructura caleidoscópica.

De tal procedimiento de transformaciones resultan diosas y dioses que aparecen en planos telúricos o celestes, diurnos o nocturnos, con atributos benignos o pretendidamente malignos, pero a fin de cuentas constituyendo, en un momento dado, binomios estructurados para, en otro instante, articular las parejas de opuestos a través de triadas que en su interconexión, dan esas formas caleidoscópicas y poliédricas, y sobre las cuales se van articulando, entre el pasado prehispánico y el ulterior proceso que ha dado pie al catolicismo popular yokot'an, ciertas constantes que entretejen ritos vinculados a danzas de carácter agrícola, simbolismos acuáticos y cuádruples vinculados a la imagen de Cristo crucificado.

\footnotetext{
${ }^{9} \mathrm{Al}$ respecto vale recordar la siguiente afirmación de Emile Durkheim: "cuando abordemos el estudio de las religiones primitivas, ha de ser con la seguridad de que éstas se sustentan en la realidad y la expresan... Los ritos más bárbaros o los más extravagantes, los mitos más extraños traducen alguna necesidad humana, algún aspecto de la vida, ya sea individual o social” (Durkheim, 1982: 2).

10 "Evolutivo", como sinónimo y reducido al proceso de lo menos a lo más y de lo inferior a los supuestamente superior.
} 


\section{Los hombres danzándose dioses}

El cuerpo tangible es la piedra con la que se esculpe el paradigma existencial humano, soma absoluta no preexiste; por el contrario, resulta de un proceso de construcción cultural (Ramírez, 2000: 235) en el que tejidos y células se difuminan ante la presencia portentosa de la metáfora. El cuerpo humano no sólo es carne y huesos, por lo que los tratados de la anatomía moderna son apenas una aproximación a él. El cuerpo humano es también una textura cultural: construcción de volúmenes y siluetas múltiples, distintas, fantasmales, siniestras, benévolas o generosas. De aquí que lo humano simultáneamente ocupe el cuerpo de los dioses, transformándose en ellos por la intermediación de la danza y la música.

Desde aquel empuñar objetos poderosos como en los dinteles de Yaxchilán que muestran a Pájaro-Jaguar y otros acompañantes bailando con el báculo hasaw-ka'an, el cetro-árbol xukpí, el k'awil de pie de serpiente, los bultos ikatz y otros elementos, amén de Pakal bailando con un hacha en una mano y en la otra con una serpiente erguida (Freidel, Schele y Parker, 1999: 257, 261 y 268-271). Pasando por las escenas del Códice de Dresde donde una zarigüieya antropomorfa carga a Chaak, a un jaguar y a los dioses E y A, y se ofrenda maíz, y pescados, incensarios quemando pom, además de aves decapitadas (De la Fuente, 2002: 161), hasta la misma danza de El Caballito Blanco con sus objetos portados, es factible observar que en todas estas escenas los cuerpos comunes y profanos devienen volúmenes, que trascendiendo su antropomorfismo, sobrevienen Caballo o Máscara, nuevos sujetos manados gracias al drama ritual. Los personajes representados por hombres ordinarios de la región, al vestirse con el atuendo ritual y llevar objetos poderosos "imbuidos de la fuerza del alma” (Freidel, Schele y Parker, 1999: 267), adquieren otra forma: sagrada y extrahumana, imagen gestada acaso junto al primer sonido musical — del tambor-, acaso el primigenio y por ello igualmente poderoso.

Nuestra danza, representada por los personajes Caballito Blanco y Máscara Roja, es acompañada musicalmente por un grupo de tamborileros, o de una pequeña banda. De manera básica consiste en que, al toque de las notas iniciales, los protagonistas se retan mutuamente alzando sus armas, para, en seguida, durante algunos minutos, batirse entre avances y retiradas, hasta lograr Caballito derribar a Máscara. Versiones específicas nos regalan escenas como las siguientes:

Máscara comienza a danzar, su blanca y larga cabellera flota a la vez que sus pies marcan los pasos sobre la tierra. Porta en su mano izquierda el abanico que ondea rítmicamente; mientras tanto, con la derecha sostiene el machete que en péndulo mueve apuntando hacia abajo, para levantarlo ante la embestida de Caballito, quien lo ataca con su espada. Se retiran entre sí, dando giros y serpenteando las armas, para arremeter en una segunda y tercera ocasiones. Entrelazados, a retiradas y avances, se alternan retumbos de los tambores con el agudo silbar de la flauta. En un cuarto ataque, Caballito derriba a Máscara; éste, en cuclillas, pasa su mano sobre la frente y mira que ha sido herido, con el mismo brazo intimida a su oponente, para enseguida con la palma izquierda 
frotar su machete amenazante. Se yergue el personaje Máscara, desplazándose en círculos, en tanto que Caballito le espera en movimientos más cortos, hasta volver a chocar sus hierros por quinta y sexta ocasiones; después, la embestida final, Caballito toca con la punta del arma el cuerpo de Máscara quien se derrumba de espaldas sobre el suelo. La música baja paulatinamente su volumen hacia el silencio, mientras cesan los últimos giros de los danzantes.

El sonar de flauta y tambores ejecutados por niños y jóvenes, en las versiones de Buenavista, es cambiada por una banda de adultos compuesta de tambora, tarola, platillos y saxofón, en Tamulté de las Sabanas. Estos conjuntos se colocan entre los espectadores, sin que su presencia reste espectacularidad a la danza; de tal forma que la música se funde con el entorno a manera de un sonido inherente al bailable ritual. Las notas de viento y golpe brotan produciendo frecuencias desde muy elevadas a profundas, haciendo vibrar el aire caliente y los tímpanos de los escuchas con la melodía, armonías y ritmo de piezas como El Tigre, en Buenavista, o géneros modernos interpretados en el caso de Tamulté.

Así es que hombres profanos con ropas sagradas "No dejan de ser humanos pero, al mismo tiempo, se transforman, y al disfrazarse y usar máscaras se vuelven receptáculo y recurso de acción de los dioses” (De la Fuente, 2002: 164). Por ello, Caballito Blanco y Máscara Roja no sólo implican a personajes obligados de una fiesta popular; en el gran drama ritual, el tiempo y el espacio son un tablado donde los actores se desbordan a sí mismos constituyéndose en hierofanía, ${ }^{11}$ de la que participan tanto el cuerpo del danzante, como el ropaje portado. A raíz de esto, toda la parafernalia adquiere connotación sagrada y, por lo tanto, significado complejo: mixtura de sentidos simultáneos.

Dada la relevancia de los objetos que coparticipan en la forma ritual adquirida es que resulta fundamental atenderlos; dicha parafernalia ritual queda constituida, en su parte sonora por

\begin{tabular}{|l|l|l|}
\hline & TAMBORILEROS & BANDA DE MÚSICA \\
\hline INSTRUMENTOS DE PERCUSIÓN & & \\
\hline TAMBORES & $\begin{array}{l}\text { Na'joben, bajo, también conocido } \\
\text { como tambor hembra } \\
\text { Ch'okjoben, mediano } \\
\text { P+kjoben de dimensiones menores }\end{array}$ & $\begin{array}{l}\text { Tambora } \\
\text { Tarola } \\
\text { Platillos }\end{array}$ \\
& $\begin{array}{l}\text { y notas más altas, nombrado } \\
\text { igualmente tambor macho; flauta o } \\
\text { pito, }+m+y .{ }^{12}\end{array}$ & \\
\hline INSTRUMENTOS DE ALIENTO & Flauta o pito, $+m+y .{ }^{13}$ & Saxofones \\
\hline
\end{tabular}

11 "El hombre entra en conocimiento de lo sagrado porque se manifiesta, porque se muestra como algo diferente por completo de lo profano. Para denominar el acto de esa manifestación de lo sagrado hemos propuesto el término de hierofanía". (Eliade, 1985: 18-19)

${ }^{12}$ Nombres en lengua yokot'an y grafías tomadas de Gómez Jiménez, et al., 1996.

${ }^{13}$ Nombres en lengua yokot’an y grafías tomadas de Gómez Jiménez, et al., 1996. 
Y en su composición teatral, por lo que se presenta en el siguiente cuadro:

\begin{tabular}{|c|c|c|}
\hline & CABALLITO & MÁSCARA \\
\hline CARACTERIZACIÓN & $\begin{array}{l}\text { Lienzo blanco, crin, ojos, orejas, } \\
\text { rienda, freno, silla de montar, } \\
\text { piernas de trapo, cáliz, hostia, } \\
\text { uvas, trigo, flores (rosas), mari- } \\
\text { posa, santo patrón, san Antonio } \\
\text { de Padua, cruz, paloma y paño } \\
\text { con cruz. }\end{array}$ & $\begin{array}{l}\text { Barba negra, boca } \\
\text { abierta, dientes mostrados, } \\
\text { prominente nariz aguileña, } \\
\text { cejas negras, ojos, protu- } \\
\text { berancia circular en la frente, } \\
\text { larga cabellera blanca, tez } \\
\text { roja u ocre claro. Cuando } \\
\text { se combina como Coyá (en } \\
\text { la versión de Buenavista), } \\
\text { porta chin-chin, mano } \\
\text { derecha, y abanico, } \\
\text { mano izquierda. }\end{array}$ \\
\hline ROPA & $\begin{array}{l}\text { Camisa en colores claros, blanco } \\
\text { y azul celeste - a excepción de } \\
\text { los cuadros azul y rojo del caso } \\
\text { de Buenavista-; y, pantalones } \\
\text { en color oscuro. }\end{array}$ & $\begin{array}{l}\text { Camisa y calzón de manta } \\
\text { blanca, o camisa blanca } \\
\text { y pantalón oscuro. }\end{array}$ \\
\hline TOCADO & $\begin{array}{l}\text { Sombrero tipo "texano", en } \\
\text { colores oscuros o, pañuelo } \\
\text { rojo (paliacate) }\end{array}$ & Cabellera blanca \\
\hline ARMAS & $\begin{array}{l}\text { Espada, hoja de doble filo con } \\
\text { punta, en uno de sus filos con } \\
\text { sangre simulada con pintura roja. }\end{array}$ & Machete, de un solo filo. \\
\hline
\end{tabular}

Comparativamente con lo anterior, es interesante considerar que entre los Pauahtunes, quienes envían el viento, está asociado el rayo y el trueno ambos simbolizados por el hacha y tambor en los códices; es pertinente para nuestro análisis subrayar que, en las representaciones de Chaac, éste aparece sosteniendo en la mano un hacha de pedernal (Ruz Lhuillier, 1995: 47- 48), respecto a lo cual Soustelle señala que dichos objetos son símbolo del rayo y el trueno (Soustelle, 1988: 178). Morley nos dice que, para revertir el peligro de eventos negativos, era menester ofrendar al dios objetos o personas en sacrificio, tal era el caso para propiciar las lluvias; también se utilizaba la sangre, humana o de algún animal, para rociar con ella a sus ídolos y embadurnarles el rostro (Morley, 1994: 207). En consecuencia, tenemos que la divinidad pluvial prehispánica queda asociada al hacha sostenida con la mano, el tambor y la sangre, componentes antiguos cercanos a los objetos de danza contemporáneos.

El poder simbólico para conducir según los deseos humanos, el cauce de los acontecimientos naturales, puede explicarse a partir de la consideración que indica que por la danza los actores de esta se transformaban en los personajes representados en un "realismo dramático mediante las máscaras y los trajes" utilizados (Freidel, Schele y Parker, 1999: 257). De esta manera, el baile sagrado es canal de trans-formación; es decir, de trascender una forma primera, para adquirir una nueva hechura y con ello otras cualidades y poderes, lo que hace concluir a 
Freidel, Schele y Parker que "Mediante la danza los seres humanos se transformaban en dioses y los dioses en seres humanos... así fuese por un momento" (Freidel, Schele y Parker, 1999: 261).

Las consideraciones de los autores referidos permiten sugerir que nuestra danza, en la medida que integra el portar espadas, machetes, sonajas y abanicos, estar teñida de rojo-sangre sacrificial, amén de asociarse con el ciclo pluvial ${ }^{14} \mathrm{y}$ los productos obtenidos de la cosecha y pesca llevados como enrama —ofrenda - al pie de san Antonio o san Francisco o Cantepec, evidencia su permanencia hasta nuestros días, como componentes de culto dedicados a hierofanías acuático-fecundativas dadoras del sustento humano.

\section{Los vértices}

Tales factores se articulan en ese continuum semiótico ya invocado, y nuevas reconfiguraciones, de vinculación poliédrica; echan mano de componentes "originalmente" pertenecientes a las semiosferas ya mesoamericana o ya ibérica, ya precolombina o ya contemporánea. Para detallar este procedimiento, volvamos a tratar los componentes de ese todo caleidoscópico en la especificidad de sus vértices.

Tambor y pito: útero/tierra - falo/lluvia. Es el redoblar de los tambores la señal que separa el tiempo y el espacio profanos de aquellos otros sacralizados por la danza. En este punto es notable dimensionar el carácter del sonido musical. Al respecto, Joseph Soler plantea la posibilidad de que la música y el habla deriven de una fuente común, por lo que flautas, tambores y cornos poseen una estrecha conexión con el "lenguaje-sonido"; refiere el ejemplo de las tribus africanas Twi y Ewe, quienes jamás dicen los nombres de sus dioses con palabras, sino que los pronuncian por intermediación de sus tambores, y afirma: "el sonido, crea un lazo misterioso que religa a todos los seres del universo" (Soler, 1987: 9).

En el contexto chontal el lenguaje-sonido es emitido por el pito y los tambores, pero me permito afirmar que es fundamentalmente la percusión, antes que la música de viento, lo que excita un sentido numinoso ${ }^{15}$ en la danza del Caballito. $\mathrm{Al}$ respecto, Pietro Scarduelli, estudiando el ritual, observa que un análisis completo de este implica explorar aspectos genéticos, fisiológicos, neurofisiológicos, cognoscitivos, operativos, individuales, sociales y ecológicos, de donde la parti-

\footnotetext{
${ }^{14}$ Las celebraciones dedicadas a san Francisco de Asís como marca del cierre de lluvias fuertes en la región.

15 "El sentimiento de criatura es más bien un momento concomitante, un efecto subjetivo; por decirlo así, la sombra de otro sentimiento, el cual, desde luego, y por modo inmediato, se refiere a un objeto fuera de mí. Y este, precisamente, es el que llamo lo numinoso. Solo allí donde el numen es vivido como presente [...], o donde sentimos algo de carácter numinoso, puede engendrarse en el ánimo el sentimiento de criatura, como su sentimiento concomitante" (Otto, 1980: 21).
} 
cipación y concentración en la acción ritual se logra mediante procesos de "sintonización” fisiológica y cognoscitiva en los que el ritmo y la repetición cumplen un papel relevante. En consecuencia, el uso de tambores, entre otros recursos rituales, conlleva movimientos repetitivos, así como estímulos visuales y auditivos, que provocan un sentimiento de unión y superación de las contraposiciones, y que induce experiencias distintas de acuerdo al ritmo adoptado, como la fusión con una potencia superior, anulación del miedo a la muerte, o un sentimiento de armonía universal. Cabe aclarar que este autor subraya que dichos impulsos rítmicos sólo tendrán efecto entre quienes comparten un mismo ámbito cognoscitivo e iguales valores normativos correspondientes a su propia cultura, como ocurre efectivamente en la comunidad chontal (Scarduelli, 1988: 27, 50, 85). Por lo tanto, y con base en lo anterior, no son las agudas notas de la flauta, sino los profundos graves de la tambora o del tambor chontal na'joben, lo que invade el ambiente sacralizado; es decir, antes que la melodía — de la flauta—, es el ritmo de las percusiones lo que finalmente convoca y reúne a los creyentes en torno de la danza, imbuidos en un sentimiento de unión y armonía.

Para Chevalier y Gheerbrant en su Diccionario de los Símbolos, el tambor implica la "emisión del sonido primordial, origen de la manifestación, y más en general del ritmo del universo", observando distintas culturas se le relaciona con los ritmos cíclicos, el trueno, el agua..., el odre celeste, el rayo, la forja y el búho, es voz de potencias protectoras de las que provienen las riquezas de la tierra, y por igual se le vincula con la guerra”. Estos autores definen que tal instrumento “... es como una barca espiritual que permite pasar del mundo visible al invisible. Está ligado a los símbolos de la medicación entre cielo y tierra”. Y, citando a Mveng, transcriben que "El tambor recapitula igualmente la dimensión femenina del hombre. Se identifica con la condición de la mujer y secunda la marcha de su destino..." (Chevalier y Gheerbrant, 1995: 972-973).

De esta manera tenemos que el carácter femenino del tambor, antes señalado, resulta coherente con las dualidades masculino-femeninas halladas en torno al culto a la Tierra y el Agua en la cultura maya prehispánica; de donde este instrumento señala el origen primigenio del Hombre, el cual se encuentra en el útero materno sagrado de una divinidad, si bien telúrica, no exclusivamente manifestada en la Tierra, sino, no hay que olvidarlo, también en el agua sagrada del líquido amniótico —-manifestado en la experiencia de todo parto y, por ende, común a las experiencias culturales de las sociedades maya antigua y chontal-, vuelta, por lo tanto, divinidad en el agua terrestre. De esta manera, el binomio sagrado Agua-Tierra queda expresado ritualmente por los tambores, de aquí que sea marca para iniciar la danza y ritmo para continuarla; es decir, el gran ritmo cósmico-uterino de los tiempos primigenios.

Consecuente con lo anterior, el pito sería símbolo fálico, entidad fecundante de la Madre Tierra. Su presencia conforma la dualidad hombre-mujer en un acto ritual propiciatorio de la fecundidad y, por lo tanto, de los mantenimientos, igual que en el pasado maya. 
Abanico-viento. En Buenavista el Coyá aparece agitando con cada mano un chinchín y un abanico, simultáneamente a los movimientos de sus pies y giros del cuerpo. En los párrafos antecedentes, Ruz Lhuillier ya nos advirtió sobre la asociación entre lluvia, rayo, trueno y viento; mientras que Jacques Soustelle indica que, en el jeroglifo de Chaac, el ojo posee la forma de T, el cual es glifo de $I k$, que simboliza la lluvia y el viento (Soustelle, 1988: 179). Morley ya había registrado el vínculo entre lluvia y viento, lo que le llevó a plantear que “... el dios del viento puede ser únicamente una manifestación del dios de la lluvia, y es posible que no haya tenido existencia separada" (Morley, 1994: 212).

Claude Lévi-Strauss, atendiendo el simbolismo en las máscaras, señala que, cuando estos objetos rituales son usados por diversas culturas dentro de una región determinada, "Son las piezas de un sistema en el seno del cual se transforman mutuamente... sólo se vuelven inteligibles merced a las relaciones que las unen” (Lévi-Strauss, 1981: 79), y agrega: “...una máscara no es ante todo lo que representa sino lo que transforma, es decir, elige no representar" (Lévi-Strauss, 1981: 124). En este sentido, si bien, en la versión de Tamulté, abanico y chinchín son componentes que no aparecen, asumiendo ambas danzas como parte de un gran sistema cultural chontal que, por lo tanto, implica transformaciones entre las comunidades que lo componen y que mantienen relaciones que las unen, me permito otorgar a la interpretación dancística de Buenavista el carácter de versión antecedente; de la cual, sugiero hipotéticamente, se hubieron de derivar las expresiones más recientes y con una mayor cantidad de componentes prestados de otros poblados, como es el caso de Tamulté. De esta manera y considerando las referencias prehispánicas que asocian la lluvia con el viento, es que desprendo la propuesta de que el abanico es el componente ritual-dancístico que representa simbólicamente al viento en esta danza.

Chinchín-lluvia. Por los mismos motivos, el chinchín, en su sonido provocado por las numerosas semillas que golpean en su interior, evoca la lluvia con su golpear sobre la tierra y el follaje, caracterizados por el múltiple y constante golpetear de cada gota chocando sobre el suelo - plano terrestre- después de haber descendido del plano celeste. Así entonces, abanico y chinchín danzan juntos como el viento y la lluvia que se acompañan durante las tormentas fecundantes de las sementeras.

Espada-rayo. La espada — española - enfrentada al machete —indígena- tiene antecedentes en las imágenes de Chaac donde suele representársele portando en la mano un hacha de pedernal que simboliza al rayo y el trueno. Por su parte, Félix Báez-Jorge refiere lo anotado por Pasztory, quien, examinando las representaciones de Tláloc en Teotihuacan, distingue a un Tláloc A, de otro Tláloc B. El primero se distingue por llevar en cada mano una vasija que reproduce su figura y un rayo "bastón serpentino", a esta versión de Tláloc se le asocia con cipactli: Tierra y Agua; mientras que al segundo se le caracteriza por mostrar una lengua 
bifurcada, y estar relacionado al jaguar, la guerra y el Agua (Báez-Jorge, 2000: 331). Considerando la presencia simbólica, en la danza del Caballito, del vientoabanico y la lluvia-chinchín, no resulta extraña la presencia de espada/machete-rayo como un derivado, transformado, del complejo simbólico del ancestral culto a Tláloc y que ahora se desdobla en nuestros dos personajes, por lo que, simultánea a la pareja de opuestos Máscara-Indígena vencido/Caballito-Español conquistador, estamos a la vez ante el binomio Máscara/Caballito, ambos insertos en una connotación acuática.

\section{Los volúmenes del jaguar. El poliédrico proceso de transformación simbólica}

La paradoja de que, en la danza de El Caballito, los chontales estarían ritualizando su derrota militar ante el invasor español encuentra ahora una dimensión, una triangulación paralela que relativiza la supuesta sacralización del pretendido conquistador ibérico. Freidel, Schele y Parker, a propósito de otras danzas mayanses que muestran pasajes de la incursión española, apuntan que:

Estas danzas de los Altos de Guatemala y Chiapas detienen la historia e incorporan a todo el mundo en el espectáculo... Las danzas modernas combinan elementos posteriores a la Conquista con mitos del Popol Vuh y supervivencias de guerra y conflicto aún más antiguas, para crear un espectáculo contemporáneo de historia. (Freidel, Schele, Parker, 1999: 286-287)

Este espectáculo contemporáneo de historia no es una referencia descriptiva de un hecho pasado, sino una interpretación, desde referencias al pasado, encaminadas hacia una comprensión del presente. Por tanto, la aparición del Caballito Blanco no ha de ser entendida obligadamente en una perspectiva unidireccional: Caballito $=$ Conquistador español. Por el contrario, debe procederse con mayor cautela y partir del carácter metafórico del rito que nos lleva a la presunción de que el equino personaje es tanto significado como significante; esto a la manera del bricolage dado por Lévi-Strauss,$^{16}$ cuyo carácter incidente se aplica a la composición heteróclita del mito, y cuya cualidad de éste transmite, evidentemente, al rito. Esto permite explicar el por qué la cultura chontal ha construido un discurso

16 “... una ciencia a la que preferimos llamar "primera” más que primitiva: es la que comúnmente redesigna con el término de bricolage. En su sentido antiguo, el verbo bricoler se aplica al juego de pelota y de billar, a la caza y a la equitación, pero siempre para evocar un movimiento incidente: el de la pelota que rebota, el del perro que divaga, el del caballo que se aparta de la línea recta para evitar un obstáculo. Y, en nuestros días, el bricoleur, es el que trabaja con sus manos, utilizando medios desviados por comparación con los del hombre de arte. Ahora bien, lo propio del pensamiento mítico es expresarse con ayuda de un repertorio cuya composición es heteróclita y que, aunque amplio, no obstante es limitado; sin embargo, es preciso que se valga de él, cualquiera que sea la tarea que se asigne, porque no tiene ningún otro del que echar mano. De tal manera se nos muestra como una suerte de bricolage intelectual, lo que explica las relaciones que se observan entre los dos" (Lévi-Strauss, 1975: 35-36). 
dancístico utilizando los materiales significantes de la conquista ibérica, respecto a lo cual son relevantes las consideraciones levistrossianas:

... lo propio del pensamiento mítico, como del bricolage..., consiste en elaborar conjuntos estructurados, no directamente con otros conjuntos estructurados, sino utilizando residuos y restos de acontecimientos;... sobras y trozos, testimonios fósiles de la historia de un individuo o de una sociedad. (Lévi-Strauss, 1975: 42)

Consecuentemente, el contexto chontal vigente obliga a una nueva adjudicación de significados y reutilización de significantes: "los significados se truecan en significantes, y a la inversa" (Lévi-Strauss, 1975: 41). Vemos así que, efectivamente, Caballito Blanco marca, por un lado, la memoria de la conquista, pero, por otro, ritualiza el tiempo cíclico de la agricultura y la pesca —-fuentes sustantivas de su reproducción material-, que de antiguo era atributo del simbolismo en torno del Jaguar. De no considerar ese juego estructural al modo del bricolage, podría llegarse a la conclusión de que ambos aspectos (Jaguar prehispánico, Caballito colonial), en principio, pudieran atribuirse a una fusión pretendidamente "descuidada" por parte de sus autores culturales; pero aquí partimos de la idea de que todo sistema cultural goza de una coherencia conceptual interna en virtud de que su lógica responde primero a causalidades endógenas y en segundo plano a las exógenas: "una estructura es un sistema de transformaciones... y que se conserva o se enriquece por el mismo juego de sus transformaciones, sin que estas lleguen a un resultado fuera de sus fronteras o reclame unos elementos exteriores" (Piaget, 1980: 9-10). ${ }^{17}$

Por lo tanto, es menester observar al sistema ritual chontal como una estructura total en sí misma, que se transforma y autorregula; como un sistema de transformaciones que son, en palabras de Piaget, "estructurantes por naturaleza... siempre y simultáneamente estructurantes y estructuradas... [y en donde]... una actividad estructurante sólo puede consistir en un sistema de transformaciones" (Piaget, 1980: 14). Y respecto a lo cual Edmund Leach apunta: "dondequiera que la idea de divinidad es representada por un objeto material... están implicadas transformaciones metafóricas y metonímicas, y este tipo de condensación entra en juego en algún punto de la serie" (Leach, 1981: 54-55).

Los documentos esgrimidos - y ya antes citados- por integrantes de la misma población yokot'an son ejemplo vivo de la pertinencia y utilidad de estas conceptuaciones teóricas. Recordemos que en dichas fuentes se afirma que, previo a la llegada de los ibéricos, se bailaba una danza nombrada "del Tigre", para lo cual los ejecutantes se "disfrazaban de dicho animal" y simulaban "pelear con un indio que se vestía de guerrero". Hasta aquí, el paralelismo entre el guión de las danzas del Tigre y del Caballito resultan constantes: esos personajes zoomorfos son representados por actores rituales humanos que figuran tales animales

${ }^{17}$ Subrayado del autor. 
por medio de un atavío; éstos se enfrentan a un guerrero indio que finalmente "simulan sacrificar en una cueva que le llaman "la cueva del K'ANTEPEC". Esta dramatización mantiene la presencia de personajes animal y humano, así como la inmolación del segundo. Tales constantes se empatan con el guión de la danza de El Caballito Blanco; aquí, por igual, aparece un personaje zoomorfo, Caballito, y un Guerrero Indio, pero sucede que dichos actores evocan el recuerdo de la conquista que en 1519 atestiguó la batalla ocurrida entre indígenas e invasores españoles y se le interpreta como la dramatización de la invasión ibérica sobre la población chontal. Sin embargo, el análisis que aquí se realiza conlleva a una visión, que, si bien no excluye dichas elucidaciones, busca complementar una exégesis de por sí más compleja.

En el documento Investigación hecha por los naturales de Buenavista..., se mencionan tres danzas: la de El tigre, la de El K'oya, y la de El Caballito. Su existencia se muestra en la misma fuente como un continuum histórico, aunque se observa el que en la segunda danza sólo participaba un protagonista: "danzando con una máscara puesta y no era acompañado por los hombres disfrazados de tigres... representado en dos formas, hombre bueno y malo". Tal seriación cronológica de esas tres danzas evidencia que Tigre y Caballito hacen las veces de significantes antes que de significados; Caballito no es significante constreñido al significado "conquista del español/derrota del indio", sino que polisémicamente integra otro significado acaso más sustantivo; es decir, que remite a orígenes primigenios de la cultura yokot'an. Esta presunción nace de la respuesta por parte de un entusiasta chontal promotor de la cultura propia, a quien preguntándole:

"¿La Danza del Caballito es sobre la conquista cuando fue derrotado el pueblo Yokot'an?"

Respondió:

"Sí, La Danza del Caballito es una danza de conquista, de cuando nos conquistaron, pero... todavía aquí estamos..."18

Ese "aquí estamos" obliga volver los ojos respecto a las implicaciones de arbitrariedad inherentes al símbolo. En este punto cabe recordar las consideraciones de Edmund Leach: “... las relaciones simbólicas son afirmaciones arbitrarias de semejanza y, por lo tanto, principalmente metafóricas...” (Leach, 1981: 21). Dicha arbitrariedad es lo que da pie a ambigüedades de sentido como el asociado con la conquista otorgado a nuestra danza, y a soslayar que estamos ante una danza inserta en un complejo ritual constituido por símbolos, ${ }^{19}$ y para lo cual aplican los principios del bricolage que contribuyen en los constructos culturales entendidos desde la mecánica poliédrica. Por ello, la danza de El Caballito es, consecuente-

\footnotetext{
${ }_{18}$ Palabras de Víctor García Salvador, promotor de la cultura chontal; Buenavista Primera Sección, municipio Centro, Tabasco, 15 de junio del 2003.

${ }^{19}$ Victor Turner señala: "El símbolo es la más pequeña unidad del ritual que todavía conserva las propiedades específicas de la conducta ritual; es la unidad última de estructura específica en un contexto ritual" (Turner, 1980: 21).
} 
mente, una escenificación metafórica bajo la cual se estructura el sistema ritual de la que forma parte; y, en tanto que estructura, le es propio el desarrollar procesos de transformación simbólica.

En los encadenamientos Caballito-Conquista se insertan otros componentes que implican vértices que conducen a otros conjuntos simbólicos como los del Caballito-Tigre-Guerrero. La continuidad histórica entre el Tigre y el Caballo, atribuida en el texto antes referido, da la clave a la paradoja de que los indígenas, rindiendo culto al pretendido símbolo de su dominio, Caballito, mantienen un continuum semiótico donde éste de significado pasa a significante, para significar al sustantivo símbolo cultural del Jaguar. Expliquémonos.

Resulta evidente que el llamado tigre nombra al mítico felino americano: jaguar (Pantera onca). De este mamífero, el Diccionario Enciclopédico de Tabasco refiere que hace medio siglo atrás su población era abundante en la sierra y manglares de ese estado (Álvarez, 1994: 361). Por su parte, María del Carmen Valverde, en su estudio sobre el jaguar en el contexto maya, señala que "es un animal nocturno y crepuscular, y de costumbres en extremo secretivas" (Valverde, 2004: 45). A ello se agrega el que jaguar y humano son hermanos gemelos en el balance de la familia ecológica del Neotrópico, siendo nuestro felino y el hombre especies que pueden matarse una a la otra, compitiendo además por el mismo tipo de presas para su alimentación (Redford y Robinson, 2002: 21-22). Este paralelismo acaso hubo participado de aquellos mitos protagonizados por jaguares, hombres y mujeres en torno de la posesión del fuego, y que llevaron a escribir a Claude Lévi Strauss:

El jaguar y el hombre son términos polares cuya oposición está doblemente formulada en lenguaje ordinario: uno come lo crudo, otro lo cocido; y sobre todo el jaguar se come al hombre, pero el hombre no se come al jaguar. El contraste no sólo es absoluto: implica que entre los dos términos existe una relación fundada en la reciprocidad nula. Para que todo lo que posee hoy el hombre (y que el jaguar no posee más) haya podido venirle del jaguar (que lo poseía en otro tiempo, cuando el hombre carecía de ello), es preciso, pues, que aparezca entre ellos el medio de una relación: tal es el papel de la mujer (humana) del jaguar (Lévi-Strauss, 1982: 87).

Esas vidas paralelas son tan significativas culturalmente que hacen del Panthera onca una hierofanía: "se le consideró, no como un dios propiamente dicho, sino como una de las manifestaciones más claras de Lo Sagrado" (Valverde, 2004: 294).

La Danza del Jaguar es prohibida ya en un nuevo contexto, el de la sujeción militar y colonización ibérica que implicó, obviamente, modificaciones en los entornos tanto natural como social de la comunidad yokot'an; es decir, en ese parentesco ecológico arriba mencionado. El carácter sacro del jaguar y el animal mismo se convierten entonces en símbolos prácticamente subversivos para con el nuevo estado virreinal imperante, ya que, como se ha señalado anteriormente, en él se sintetiza de manera sobresaliente la sacralidad simbólica nativa que se 
pretende sojuzgar; cabe observar que cuando Bernardino de Sahagún escribe sobre los "animales, aves, peces, árboles, hierbas, flores, metales y piedras, y de los colores", inicia su descripción con el tigre, "príncipe y señor de los otros animales" (Sahagún, 1979: 621). Su anulación del sistema simbólico del creyente ahora avasallado implicó el despojo de un significante que era vehículo de significados sustantivos para la cultura nativa; la estrategia por adoptarse para contrarrestar este saqueo semiótico fue la siguiente: si el símbolo censurado es el tigre, entonces cámbiese el significante pero manteniendo los significados. El resultado de tal proceso semiótico fue la sustitución del tigre-jaguar por el caballo. Esto ya se ha dicho repetidamente, pero ipor qué es el caballo quien sustituiría al jaguar? Para ello comencemos observando las características equinas.

Queda claro el significado del cuadrúpedo en función de la pretendida conquista ibérica, esa fusión corporal entre el jinete y su cabalgadura, por igual, remite sin mayor dificultad a la interpretación atribuida al nativo: "Y aquí creyeron los indios que el caballo y el caballero eran todo uno, como jamás habían visto caballos" (Díaz del Castillo, 1979: 64); y el guión y coreografía de la danza refieren la historiografía de aquel periodo donde, al menos militarmente, el indígena fue derrotado. Pero la postura aquí manejada no se conforma con retomar una interpretación tan explícita en una representación ritual, por definición, metafórica; consecuentemente partimos de la sospecha de que, detrás de ese sentido explícito y obvio que hace referencia a la subordinación chontal durante la Colonia, existe un significado en tanto que el texto explícito no es el significado en sí, sino el significante.

En consecuencia, la narrativa de la danza no es únicamente el texto explícito (significante), sino un contenido ritual metafórico donde se guardan sus significados. Para exhumarlo razonemos junto con Edmund Leach quien considera que "cuando A y B proceden de contextos diferentes, estamos tratando con símbolos y las relaciones son principalmente metafóricas" (Leach, 1981: 53). Es así que en el bricolage de la composición dancística entran en juego tanto dispositivos de cuna precolombina como colonial; es decir, factores cuyos orígenes corresponden a contextos diferentes, pero que en un punto temporal —el momento histórico del encuentro chontal/hispano-. Esas dos líneas cronológicas constituyeron un vértice en el espacio geográfico y simbólico yokot'an.

En tal perspectiva regresemos a la plástica de la danza y prestemos particular atención a la contextura iconográfica del Caballito Blanco. En las tres versiones conocidas (Tamulté de las Sabanas y las dos de Buenavista), se ostenta siempre una cruz (figuras 5, 6 y 7), emblema que se reitera en la protuberancia de la frente de Máscara Roja (figura 8); ${ }^{20}$ por igual, en el manto blanco de Caballito,

\footnotetext{
${ }^{20}$ Resulta importante indicar que, en la también danza chontal, conocida bajo el nombre de David y Goliat, protagonizada por los habitantes de Cúlico, la máscara con que se representa a Goliat muestra una igual protuberancia atribuida obviamente a la herida propinada por su joven oponente David, en el relato bíblico, que en parte de su guión reproduce este bailable integrado a la ritualidad en honor de la Virgen de la Concepción (véase: Rubio, 1996b).
} 


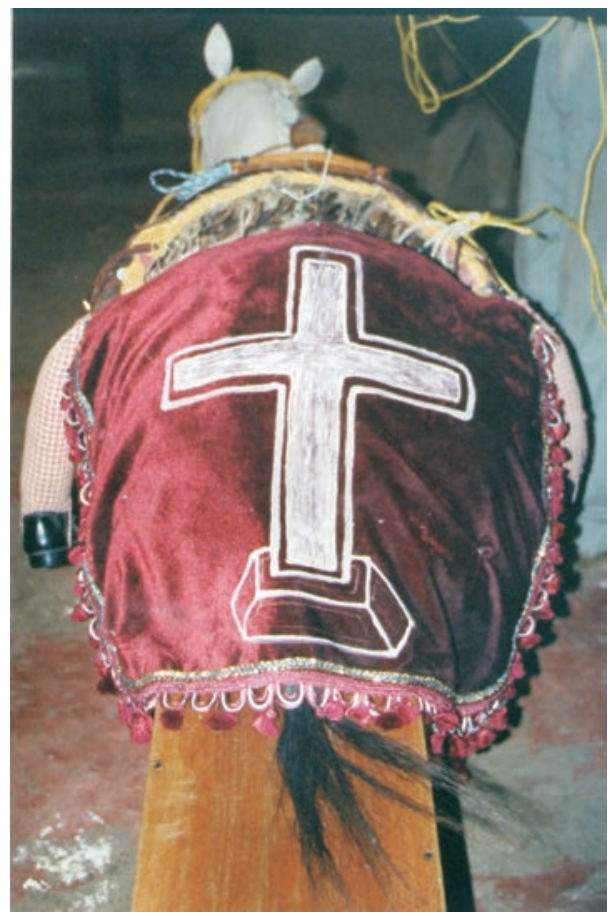

Figura 5. Cruz, Caballito de Buenavista. Foto de Juan Luis Ramírez Torres

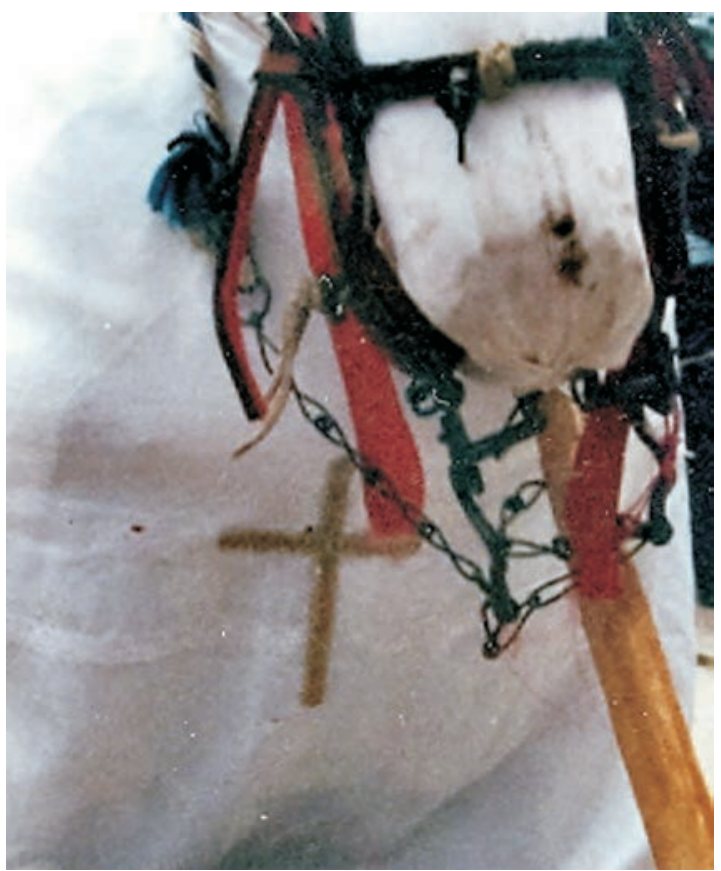

Figura 6. Cruz, Caballito de Tamulté de las Sabanas. Foto de Juan Luis Ramírez Torres 


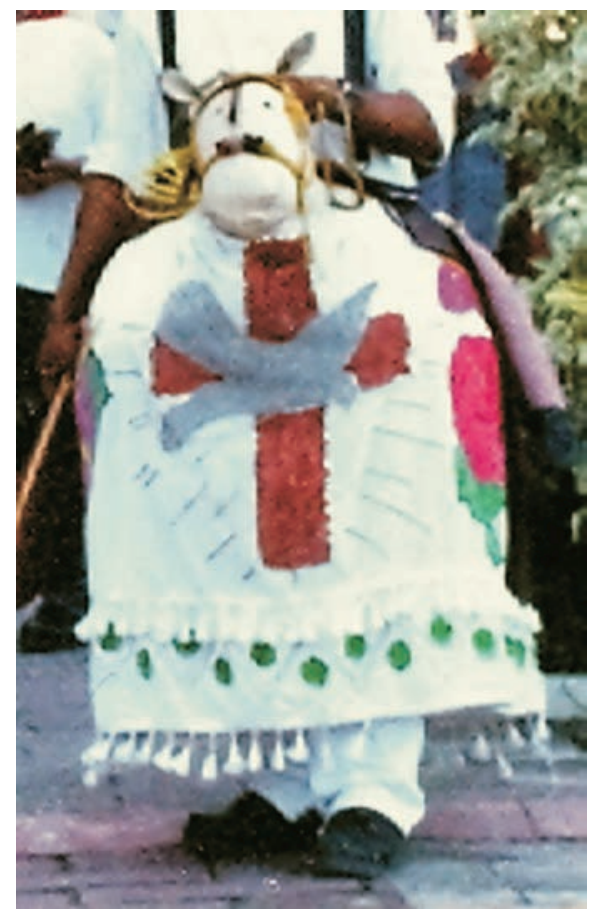

Figura 7. Cruz, Caballito de Buenavista. Foto de Juan Luis Ramírez Torres

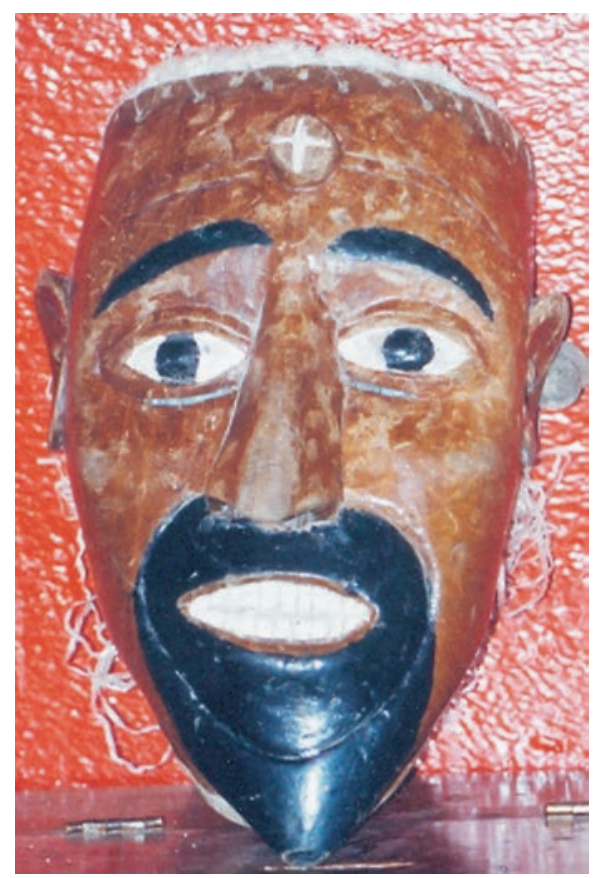

Figura 8. Cruz en Máscara Roja.

Foto de Juan Luis Ramírez Torres 
suelen bordarse o pintarse representaciones de flor o mariposa (figura 9). Estas imágenes cruciformes y florales, amén de la mariposa, evocan diversas versiones precolombinas del jaguar. Las manchas características de este animal, o, en otras palabras, los rosetones negros que le distinguen (Ruíz Gallut, 2005: 30-31) gráficamente, se asocian con la silueta de la flor; así es que resulta particularmente relevante el jaguar florido de los murales de Teotihuacan (Séjourné, 2002: 274275) que empatan con lo señalado por María del Carmen Valverde: "todas las imágenes del carnívoro con motivos vegetales y acuáticos, como flores, lirios, jades, chorros de agua, etc., aludirían precisamente a este mismo complejo simbólico" (Valverde, 2004: 292).

En el marco de la gran matriz cultural y simbólica que ha sido Mesoamérica, se encuentran frecuentemente asociados la flor, la mariposa y el corazón en el campo semántico-plástico del jaguar. En los murales de Tetitla, en Teotihuacan, se tiene la imagen de los felinos que "emiten de sus bocas, a la manera de aliento, corazones incrustados con jade, reducidos, por medio del corte horizontal, al puro movimiento de tres espirales" (Séjourné, 2002: 263); Doris Heyden refiere, para la zona de Xochimilco, relieves líticos que vinculan flores con mariposas y

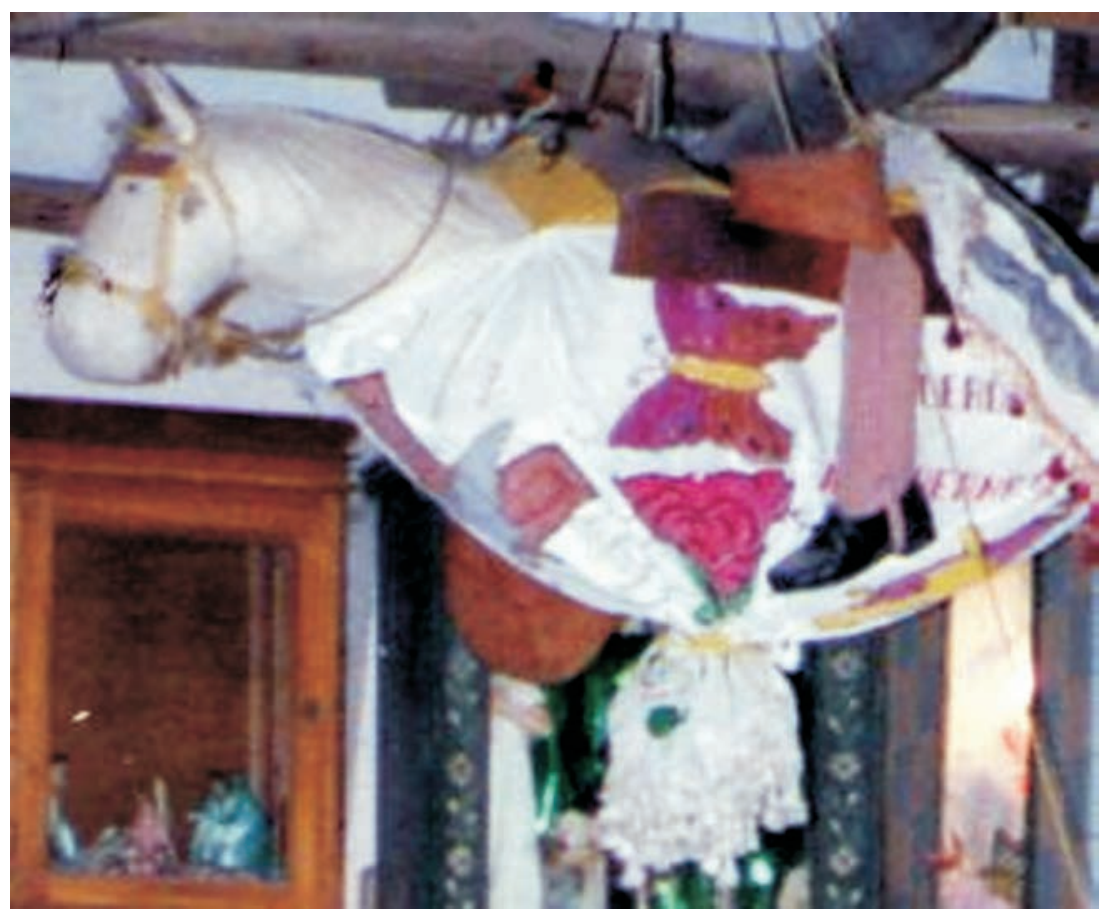

Figura 9. Mariposa y flor en el Caballito. Foto de Juan Luis Ramírez Torres 
el jaguar; estos encadenamientos, ahora observados en el Códice Matritense, se extienden nuevamente al corazón: corazones floridos (Heyden, 1985: 98, 99 y 101), que ensanchan su complejo semiótico, en el sentido de la flor en Teotihuacan, a la cueva: corazón de la tierra, junto con el jaguar relacionado con el inframundo, como en el vocablo Tepeyólotl, corazón del cerro (Heyden, 1985: 69).

Tal complejo simbólico constituido por flor-mariposa-corazón-jaguar lo encontramos conectado en la cadena flor-mariposa-Caballito, y para lo cual creemos hallar lo relativo al corazón de sacrificio en la oblación de sí mismo que hace Máscara, la cual en su purpúreo color lleva el signo de la sangre ofrendada. ${ }^{21} \mathrm{De}$ esta suerte es que se insinúa un juego dialéctico donde lo uno se desdobla en dos opuestos mutuamente dependientes, lo cual deriva la interpretación de que Caballito y Máscara son la misma personificación del Jaguar; en aquél se representa una parte de sus atributos: entidad florida, significante de las abundancias y frutos de la tierra; en éste, el guerrero inmolado es el tributo entregado para hacerse merecedor de los dones telúricos. Esto explicaría la individualidad del personaje Coyá, quien, en la versión de la danza en Buenavista, inicia la procesión con la enrama rumbo a la iglesia, para enseguida transformarse el danzante, en una parada de la romería, en Máscara Roja, quien ahora cae bajo la espada de Caballito. Ocurrido esto se lleva posteriormente la ofrenda en alimentos, bebidas y ceras al pie del santo patrón donde terminan las celebraciones en honor de san Antonio de Padua.

Resulta entonces un sistema ritual integrado por las asociaciones tambor-pitoútero-tierra-lluvia, con abanico-viento, chinchin-lluvia, machete-rayo, más flor-mariposa-Caballito, y su proyección retrospectiva para con flor-mariposa-corazón-jaguar; encadenamientos estos que han de dimensionarse no en forma lineal, sino múltiple, poliédrica (figura 10). Todo lo cual se enmarca ahora en un discurso asumido como cristiano y en donde la Cruz ofrece el referente simbólico de ello, pero que, en un juego poliédrico, nos remite nuevamente a símbolos primigenios chontales, ya que la Cruz, como las exhibidas en el jamelgo o la frente del guerrero, transita del símbolo cristiano al simbolismo mesoamericano del cosmos nativo: cuatro puntos y el centro; símbolo fundamental de toda geometría terrestre y celeste en la cosmología americana (Valverde, 2000: 135), y por ende, de la Mesoamericana y mayanse. Por ello, en una reinterpretación dialéctica, en "la imagen de la Santa Cruz se han camuflado las antiguas representaciones en torno a las diosas agrarias y sus atributos de fertilidad y mantenimientos, que implican la propiciación pluvial” (Báez-Jorge, 2000: 338). Sin embargo, dejemos en duda si una de las dos partes camufla a la otra, y quedémonos con el proceso poliédrico por medio de cual la Cruz sintetiza —en una geometría tridimensional (figura 10) — aguas fecundantes, fertilidad para los cultivos y los humanos, y abundancia de mante-

\footnotetext{
${ }^{21}$ No se aborda la similitud de forma entre los glifos de flor y la forma cónica invertida en la careta de Máscara, porque se considera una interpretación particularmente audaz y riesgosa, pero se ha preferido, en este punto, no dejar de señalarlo.
} 


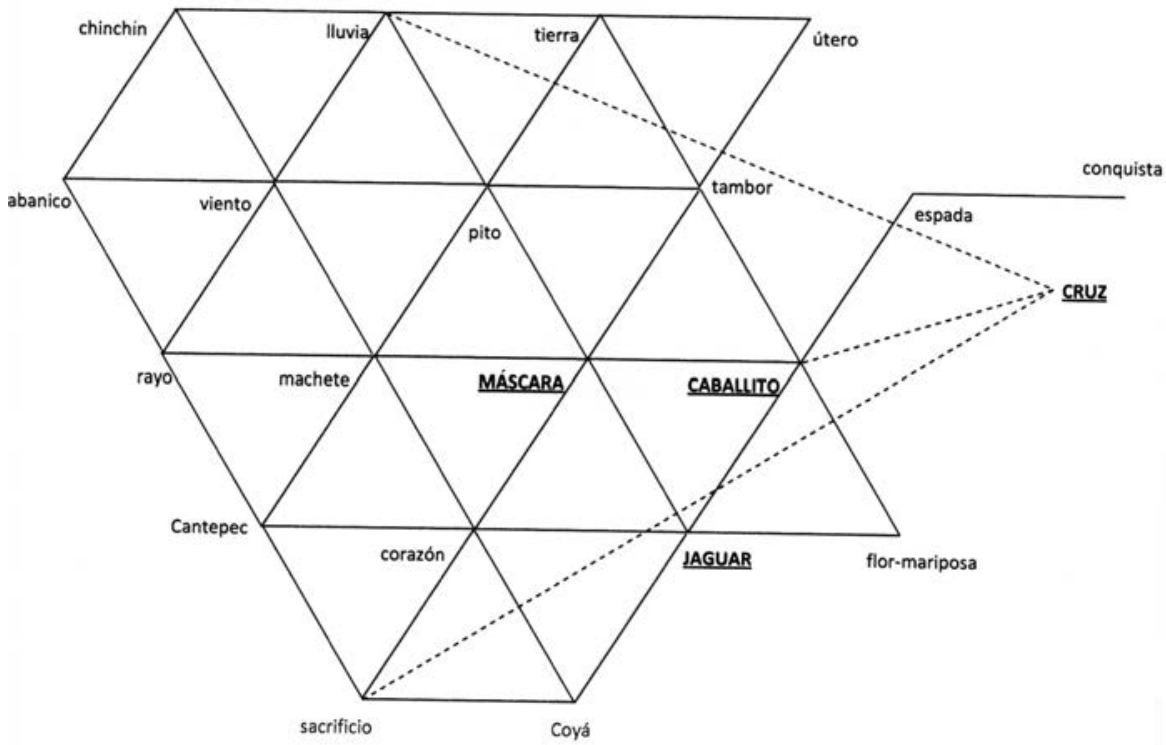

FIGURA 10. Vinculaciones poliédricas.

Dibujo: Juan Luis Ramírez Torres

nimientos; esto junto con la representación, en el mismo símbolo, del sacrificio en sangre del hombre — símil de Jesucristo: Dios en la tierra— precisamente para hacerse acreedores de lluvias, cosechas y pesca.

En consecuencia, Caballito Blanco-Jaguar Florido es corazón de la tierra, representación telúrica del hábitat humano, plano terrestre, cuatripartito y cruciforme, sobre el cual se gestan los mantenimientos; para acceder a ellos es menester ofrendarse en sacrificio, Máscara Roja, teñida en sangre, durante el duelo en la tormenta entre el trueno del choque de los aceros en su enfrentamiento al conquistador. Su muerte deja tras de sí la tierra de cuyas cosechas se nutrirán enramas ofrecidas al pie de sus santos intermediarios, ya sea san Antonio de Padua, ya san Francisco de Asís. Queda cumplida entonces la llegada de Cantepec, abundancia desde el corazón de la tierra, del jaguar, significado por el capítulo de dominio ibérico, de Caballito, pero que, a pesar todo, sigue dando vida al Chontal, porque todavía siguen aquí.

\section{BIBLIOGRAFÍA}

Álvarez, José Rogelio (director)

1994 Diccionario Enciclopédico de Tabasco. Villahermosa: Gobierno del Estado de Tabasco; 2 tomos. 
Báez-Jorge, Félix

2000 Los oficios de las diosas. Xalapa: Universidad Veracruzana.

Chevalier, Jean y Alain Gheerbrant

1995 Diccionario de los símbolos. Barcelona: Herder.

De la Fuente, Beatríz

2002 "El arte como expresión de lo sagrado", Religión maya, Mercedes de la Garza

Camino y Martha Ilia Nájera Coronado (eds.). Madrid: Trotta (Enciclopedia Iberoamericana de Religiones, vol. 2), 139-169.

Díaz del Castillo, Bernal

1979 Historia verdadera de la conquista de la Nueva España. México: Promexa Editores.

Durkheim, Emile

1982 Las formas elementales de la vida religiosa. Madrid: Akal.

Eliade, Mircea

1985 Lo sagrado y lo profano. Barcelona: Labor/Punto Omega.

1986 Tratado de historia de las religiones. México: Ediciones Era.

Freidel, David, Linda Schele y Joy Parker

1999 El cosmos maya. Tres mil años por la senda de los chamanes, Jorge Ferreiro Santana (trad.). México: Fondo de Cultura Económica.

Gómez Jiménez, Pablo, Silvia Patricia Aquino Zúñiga e Hilda Ofelia Estrada Gómez

1996 "Los siete pulmones de una raza”, Correo del Maestro, (5): 44-48. México:

Uribe y Ferrari Editores.

Heyden, Doris

1985 Mitología y símbolos de la flora en el México Prehispánico. México: Universidad Nacional Autónoma de México.

Incháustegui, Carlos

1985 Chontales de Centla. El impacto del proceso de modernización. Villahermosa:

Gobierno del Estado de Tabasco/Instituto de Cultura de Tabasco.

Investigación hecha por los naturales de Buenavista. Tamulté de las Sabanas

s.f. $\quad$ Centro. Villahermosa: Mimeografiado.

Landa, fray Diego de

1982 Relación de las cosas de Yucatán. México: Porrúa.

Leach, Edmund

$1981 \quad$ Cultura y comunicación. La lógica de la conexión de los símbolos. Una introducción al uso del análisis estructuralista en la antropología social. Madrid: Siglo XXI de España Editores. 
Lévi-Strauss, Claude

1975 El pensamiento salvaje. México: Fondo de Cultura Económica.

1977 Antropología Estructural. Buenos Aires: Editorial Universitaria de Buenos Aires.

1981 La vía de las máscaras. México: Siglo XXI Editores.

1982 Mitologías. Lo crudo y lo cocido. México: Fondo de Cultura Económica.

Lewis, Oscar

1986 Ensayos antropológicos. México: Grijalbo.

Lotman, Iuri Mijáilovich

1996 La semiosfera I. Semiótica de la cultura y del texto. Madrid: Cátedra.

Martínez Assad, Carlos

1996 Breve historia de Tabasco. México: Fondo de Cultura Económica/El Colegio de México.

Mora, Teresa y Yolotl González

1981 "La celebración de los muertos entre los chontales", Dos ceremonias para los muertos: en Cholula, Puebla y entre los chontales de Tabasco, Etnografía; Teresa Mora, Yólotl González y Silvia Ortiz Echaniz (comps.). México: Instituto Nacional de Antropología e Historia, Dirección de Etnología y Antropología Social (Cuadernos, 29), 1-15.

Morin, Edgar

2005a Introducción al pensamiento complejo. Barcelona: Gedisa.

2005b El paradigma perdido. Barcelona: Kairós.

Morley, Sylvanus Griswold

1994 La civilización maya. México: Fondo de Cultura Económica.

Nájera Coronado, Martha Ilia

2002 "Rituales y hombres religiosos", Religión maya, Mercedes de la Garza Camino y Martha Ilia Nájera Coronado (eds.). Madrid: Trotta (Enciclopedia Iberoamericana de Religiones, vol. 2), 115-138.

Navarrete, Carlos

1971 "Prohibición de la danza del Tigre en Tamulté, Tabasco en 1631", Tlalocan, VI (4): 374-376. México: Instituto Nacional de Antropología e Historia.

Otto, Rudolf

1980 Lo santo. Lo racional y lo irracional en la idea de Dios. Madrid: Alianza Editorial.

Piaget, Jean

1980 El estructuralismo. Barcelona: Oikos-Tau.

Popol Vuh

1986 Adrián Recinos (trad., introd. y n.). México: Fondo de Cultura Económica. 
Ramírez Torres, Juan Luis

2000 Cuerpo y dolor. Semiótica de la anatomía y la enfermedad en la experiencia humana. México: Universidad Autónoma del Estado de México (Cuadernos de Investigación, Cuarta Época/10).

2003 "El binomio madre-hijo: paradigma primigenio y sacralización femenina", Religión y etnicidad. La religión en el Nuevo Milenio, una mirada desde los Andes, IX Congreso de la Asociación Latinoamericana de Educación Radiofónica. Lima: Pontificia Universidad Católica del Perú, 41-52.

Redford, Kent H. y John G. Robinson

2002 "Introducción”, El jaguar en el nuevo milenio, Rodrigo Medellín y otros (comps.). México: Fondo de Cultura Económica/Universidad Nacional Autónoma de México/Wildlife Conservation Society, 21-24.

Rubio, Miguel Ángel

1995 La morada de los santos. Expresiones del culto religioso en el sur de Veracruz y en Tabasco. México: Instituto Nacional Indigenista/Secretaría de Desarrollo Social.

1996a "El caballito blanco: una interpretación no-verbal de la victoria española", Las danzas de conquista. I. México contemporáneo, Jesús Jáuregui y Carlos Bonfiglioli (coords.). México: Consejo Nacional para la Cultura y las Artes/Fondo de Cultura Económica, 229-253.

1996b "David y Goliat: el eterno conflicto entre el bien y el mal", Las danzas de conquista. I. México contemporáneo, Jesús Jáuregui y Carlos Bonfiglioli (coords.). México: Consejo Nacional para la Cultura y las Artes/Fondo de Cultura Económica, 119-143.

Ruiz Gallut, María Elena

2005 “Tras las huellas del jaguar en Teotihuacan”, Arqueología Mexicana, XII (72): 28-33. México: Raíces.

Ruz Lhuillier, Alberto

1992 El pueblo mayas. México: Salvat.

1995 Los antiguos mayas. México: Fondo de Cultura Económica.

Ruz, Mario Humberto

2002 “'Amarrando junto'. La religiosidad maya en la época colonial”, Religión maya, Mercedes de la Garza Camino y Martha Ilia Nájera Coronado (eds.). Madrid: Trotta (Enciclopedia Iberoamericana de Religiones, vol. 2), 247281.

Sahagún, fray Bernardino

1979 Historia General de las cosas de Nueva España. México: Editorial Porrúa.

Scarduelli, Pietro

1988 Dioses, espíritus y ancestros. Elementos para la comprensión de sistemas rituales. México: Fondo de Cultura Económica. 
Séjourné, Laurette

2002 Arquitectura y pintura en Teotihuacan. México: Siglo XXI Editores.

Soler, Josep

1987 La música. I. De la época de la religión a la edad de la razón. Barcelona: Montesinos Editor.

Soustelle, Jacques

1988 Los mayas, Jorge Ferreiro (trad.). México: Fondo de Cultura Económica.

Thompson, Eric S.

1992 Grandeza y decadencia de los mayas. México: Fondo de Cultura Económica.

Turner, Victor

1980 La Selva de los Símbolos. Madrid: Siglo XXI de España Editores.

Uribe Iniesta, Rodolfo y Bartola May May

2000 T'an i K'ajalinYokot'an (Palabra y pensamiento Yokot'an). México: Universidad Nacional Autónoma de México/Fondo Nacional para la Cultura y las Artes.

Valverde, María del Carmen

2000 "La cruz en la geometría del cosmos maya", Estudios de Cultura Maya, XXI: 135-145. México: Universidad Nacional Autónoma de México, Instituto de Investigaciones Filológicas, Centro de Estudios Mayas.

2004 Balam. El jaguar a través de los tiempos y los espacios del universo maya. México: Universidad Nacional Autónoma de México, Instituto de Investigaciones Filológicas, Centro de Estudios Mayas. 
